\title{
Shipwreck evidence from Kilwa, Tanzania
}

Edward Pollard and Richard Bates

University of St Andrews, Department of Earth and Environmental Sciences, Irving Building, St Andrews, KY16 9AL United Kingdom

edward.pollard@biea.ac.uk, crb@st-andrews.ac.uk

Elgidius Ichumbaki

University of Dar es Salaam, Department of Archaeology and Heritage, Dar es Salaam, Tanzania, ichumbaki@udsm.ac.tz.

Caesar Bita

National Museums of Kenya, Fort Jesus, Mombasa, P.O. Box 82412, Kenya, mcbita@museums.or.ke/mcbita@yahoo.com

This paper reports on the artefacts and environment of marine ballast and pottery sites identified through inter-tidal and underwater survey around Kilwa, Tanzania, one of the most important medieval sultanates along the east African coast. An inter-tidal site on the limestone fringing reef on the approaches to Kilwa Kisiwani Harbour and an underwater site within the harbour have been dated from associated pottery to $c .8$ th-10th century and the 13 th-16th century respectively. The presence of exotic basalt ballast is discussed as an indicator of wreck-sites.

Ikisiri: Makala hii inaelezea ugunduzi wa viashiria vya meli kale mbili zilizozama katika mwambao wa pwani ya Kilwa Kisiwani zikiwa zimesheheni badhaa mbalimbali, vikiwemovyombo vya udongo. Soroveya iliyofanyika ndani ya bahari na maeneo ya fukwe za mwambao wa Kilwa Kisiwani, mojawapo ya miji mikongwe katika Pwani ya Afrika Mashariki, ilibainisha kwamba, meli mojawapo ilizama katika lango kuu la kuingilia bandari ya Kilwa Kisiwani, ilihali nyingine ilizama pembezoni mwa 'jiwe la jahazi'. Masalia ya meli kale hizi pamoja na bidhaa zilizokuwemo ndani vinaashiria kwamba tukio la kuzama kwa meli mojawapo lilitokea kati ya karne ya nane na ya kumi, ilihali meli nyingine ilizama kati ya karne ya kumi na tatu na ya kumi na sita. Ugunduzi huu unatanabaisha kuwepo kwa mahusiano ya kibiashara baina ya wenyeji wa pwani ya Kilwa na kati ya mataifa ya Uarabuni, 'mashariki ya kati' na 'mashariki ya mbali' kwa kipindi cha kati ya karne ya nane na ya kumi na sita--takribani miaka 1300 iliyopita.

Key words: Kilwa, Tanzania, medieval, shipwrecks, basalt ballast. 
The east African coast, popularly known as the Swahili coast, extends $3000 \mathrm{~km}$ from Somalia in the north through Kenya and Tanzania to Mozambique in the south (Fig. 1). This coast was played an important role in the transoceanic Indian Ocean maritime commerce in which mangroves, gold, ivory and slaves were exported, and cloth, glass, beads and incense imported. It also includes the islands of Comoro and northern Madagascar. Sailing between these lands and their settlements has been, and is still, based on regular and predictable monsoon winds linking Arabia, the Indian subcontinent and Africa. Historical coastal settlements of Mogadishu, Lamu, Zanzibar, Kilwa and Sofala were important ports of call for merchant shipping, strategically sited along busy sea lanes. The underwater environment along the coast is therefore the likely repository of shipwrecks, abandoned boats, goods lost overboard, anchors and other maritime debris. Information from shipwrecks, however, has been lacking, limiting our understanding of the trade, marine subsistence and seafaring technology of the east African coast (Breen and Lane, 2003; Lane, 2005). Although this coast is dotted with historic settlements at close proximity to the sea, archaeological research has provided minimal insight into the specifically maritime aspects of these communities. The dangers of shipping in ancient times are known and, many western shipwrecks are reported lost in these waters (Guinote et al., 1998; Patience, 2006; Ichumbaki, 2015), but integrated surveys using marine geophysics, ethnography and cultural landscape studies to record the medieval maritime archaeology of this coast are sparse (e.g. Forsythe et al., 2003; Jeffery and Parthesius, 2013).

This paper reports on evidence of two sites discovered from inter-tidal and underwater survey around Kilwa, one of the most important sultanates along the east African coast. This work is key to fusing archaeological evidence with information from historical documents, ship engravings and ethnographic data on vernacular boats that has been gathered along the coasts of Oman, India and east African coast. This process has been severely hampered by the low number of known nonEuropean shipwrecks in the Indian Ocean. The sites discussed here by the investigators at Kilwa are therefore timely.

\section{Medieval ocean trading vessels}

Evidence for early Indian Ocean trading vessels comes in the form of historical documents, ship engravings, anchors and shipwrecks. Ibn-Jabyr, in the 8th-9th-century, recorded vessels at the Red Sea port of Aydhab that were carvel-built with planks stitched with coconut fibre through holes bored at intervals near the edges of adjacent planks (Hourani, 1995: 91-3). Investigations at Lamu, Kilepwe, Gede and Mtwapa in Kenya, and Kilwa and Ras Mikumbi in Tanzania have yielded boat illustrations and graffiti (Kirkman, 1964; Garlake and Garlake, 1964; Gilbert, 1998). Ship engravings are typically found on the outer walls, outer windows and door jambs of mosques, or near the main entrances of domestic buildings. Garlake and Garlake believed them to be charms or votive offerings for the safety of the vessel depicted. A 15th-century engraving from the Barrel 
Vaulted House at Songo Mnara near Kilwa shows the swan-necked bow typical of the mtepe, an east African sewn-plank ocean-going cargo vessel, with a pennant flying from its mast. Three 15thcentury Kilwa engravings from the Great Mosque have similar curved, flared bows but with oculi and tasselled and bobbled amulets hanging from them. They appear to have yards supporting square sails and, at the foot of the sail, a spreader yard (Chittick, 1974: 265-6).

The remains of medieval ships and maritime equipment are very limited with, perhaps the exception of anchors. Underwater surveys at the channel entrance to the ancient port of Mombasa recovered three stone anchors; of these, one is an Indo-Arabian type while the other two are composite types, that is wooden anchors weighted with stones (Bita and Wanyama, 2011; Bita and Tripati, 2015). The shape and size of the three stone anchors resemble others found along the Indian and Sri Lankan coasts, at Qalhat, Oman, Mogadishu, and the Mediterranean region (Chittick, 1974: 414; Souter, 1988: 331-42; Tripati et al., 1998: 1-8; Vosmer, 1999: 248-63; Tripati, 2003: 93-106; Gaur et al., 2008: 24-57). An Indo-Arabian type stone anchor shank (1.2m long and 0.35m wide) was recorded at Kilwa by Chittick (1974: 414) near the top of a steeply sloping bank to the west of the main town, though by 2004 it was on the foreshore below the cliff (Pollard, 2008a). This type of anchor consists of a long, flat-sided shaft, slightly thicker at one end in which two rectangular holes were set at right-angles to each other. Similar anchors have been dated to the 11th century AD at Siraf in the Gulf (Whitehouse, 1970: 14-15).

Categorical archaeological evidence for medieval ships and associated maritime trade would come from a shipwreck, but finds are exceptionally rare in the western Indian Ocean. Ships were wrecked as the 10th-century Arab historian and geographer Al-Masudi recorded a Persian shipwreck returning from Qanbalu (an unidentified entrepôt on the east African coast) (Sprenger, 1841: 260-3).

Shipwreck remains have been found in the Red Sea at Black Assarca Island, Eritrea, where Pedersen (2008) recorded amphoras and wood on the seabed among sand, silt and coral from a shipwreck dating to the 5th-7th century AD. Other artefacts included one ballast stone, greenishblue glass probably from a wineglass or goblet, and a lead globular counterweight for a steelyard. No evidence was found of the ship's structure though Pedersen considered further excavation may reveal hull remains under the amphoras that could give insights into the seafaring technology and origin of the ship. The ship was probably involved in the trade of bulk items, along with perhaps some luxury goods as indicated by the glass piece (Pedersen, 2008: 90-1).

The Kadakkarappally boat excavated on land at Kerala, SW India, has been described by Tomalin et al. (2004). It is a 13th-15th-century double-masted flat-bottomed boat, $18.7 \mathrm{~m}$ in length and $4.05 \mathrm{~m}$ in width. It has a double-planked hull and the bow rises to a point. The stern end had been destroyed, but loose timbers suggested it had a transom. Longitudinal strength comes from 
two chine strakes. Ten frames divide the boat into 11 compartments and provide transverse strength. Iron nails and wooden pegs were used in the construction with the outer planking secured to the inner planking by square-sectioned iron nails clenched over roves. At the chines the two layers have been additionally secured with square wooden pegs. Nails in the bottom planking of the boat are without roves and in places look like they have been driven through a rectangular lap-joint between adjacent bottom planks. Iron spikes and square-sectioned wooden pegs were employed to fasten the frames to the planking. Several transverse rows of cleats carved into the inner planks of the boat suggest that the planks may have been held together through compression by lashings. A few rope fragments remain within the cleats. Both masts had been destroyed but the mast-steps remain. One mast-step is in the centre of the boat with the other in the bow portion. The sockets for inserting the masts are only $50 \mathrm{~mm}$ deep suggesting further support for the mast was needed. A stone (of beach rock or kankar stone) found in the 4th compartment from the bow narrowed at one end and could be an anchor, although it has no hole to fasten the rope, and could also be ballast (Tomalin et al., 2004: 256). Tomalin et al. considered that the lack of cargo or significant ballast suggested the vessel was deliberately abandoned. The flat bottom and strong double planking indicates suitability for shallow backwater channels. Although sewn planks ships are presumed commoner in the Indian Ocean during the Medieval period, iron-fastened Chinese junks visited Kerala from the 6th century AD, and under the Tang dynasty (7th-10th centuries) Malabar became the westernmost destination for Chinese ships (Tomalin et al., 2004: 259). The use of lashings through cleats or 'lugs' is a fastening technique characteristic of Southeast Asian boat building and these vessels also sailed off the Malabar coast during the Medieval period.

There is some evidence for western Indian Ocean seafaring technology in the eastern Indian Ocean from the 9th-century Belitung shipwreck in Indonesia. Flecker (2001) described the ship as shallow-draughted, designed to travel lightly over the water, with a keel length of $15.3 \mathrm{~m}$, up to $5.1 \mathrm{~m}$ width, and possessing a sharp bow with little rake. Hull planks were stitched together with cross-stitched seams, wadded inside and out, but without use of dowels in edge joints. Frames and through-beams were lashed to the hull. The anchor was grapnel-type with the shank of wood and the arms of iron. The voyage's origin is unknown, but cargo finds included ten tonnes of lead ingots, thought to be paying ballast, and Chinese ceramics mostly from 9th-century Changsha kilns. Non-ceramic cargo included gilt silverware, bowls, spoons, a flask, Chinese mirrors, cast-iron cauldrons, copper-alloy bowls, grindstones and a blue glass Middle Eastern bottle, copper-alloy scale weights, a scale bar, cut black coral, dice carved from bone or horn, an ink-stone with two short legs and a carved butterfly design, and iron-tipped arrows (Flecker, 2001: 339-42).

The few marine surveys undertaken on the Swahili coast have documented a number of sites of potential interest on the seabed. A geophysical survey of Mombasa Island revealed numerous 
underwater sites, some of which may be shipwrecks (Forsythe et al., 2003; Quinn et al., 2007; McConkey and McErlean, 2007). In Lamu, surveys have recovered anchors, wooden features and Chinese porcelain on the seabed along Pate Bay, including a pot with dragon emblems typical of Chinese motifs of the 14th century AD (Bita and Wanyama, 2007; Bita, 2013; 2015). Dragon motifs are emblems of the Chinese Ming Dynasty Emperors. During the Ming dynasty, the Chinese are said to have launched various missions to the African continent and one of the junks is said to have sunk near Pate Island (Inghams, 1962: 5; Kirkman, 1964: 86-9).

Maritime surveys in Malindi have documented several potential sites, but most are yet to be confirmed as shipwrecks or other features. In Ungwana Bay, sailors have commented on unusual structures on the seafloor around the 'Mambrui Lump', a feature that rises some $30 \mathrm{~m}$ from the seafloor, but these wait to be investigated. However, a wooden shipwreck containing 14th-15thcentury Chinese and Indian pottery off Leopard Bay reef has been identified (Patience, 2006: 131; Bita, 2013). Further, a 16th-century shipwreck in Ngomeni, $30 \mathrm{~km}$ north of Malindi Town, has produced huge amounts of Islamic and Far East wares dating to the 13th to 15th century (Bita, 2014). In this case, the timbers are fastened together with iron nails suggesting a different tradition of boat construction to that of the western Indian Ocean. Moreover, the presence of copper ingots with a visible trident seal similar to the Fugger family crest suggests this may be a Portuguese rather than an Arabic vessel. The Fuggers were a prominent 16th-century family of merchants and bankers from Germany who, together with others, such as the Welser family, supplied merchandise that formed part of the commercial artery of the Portuguese crown (Chalmin, 1987).

\section{Kilwa background}

The Kilwa ria or bay, situated about $250 \mathrm{~km}$ south of Dar es Salaam, is founded on coral limestone along the ocean margins with sandstones and conglomerates landward (Fig. 2). A number of islands are situated in the ria, of which Kilwa Kisiwani and Songo Mnara are the largest. Kilwa Kisiwani is separated from the mainland to the north by a deep channel 1-2 km wide: this whole area is referred to as Kilwa Kisiwani Harbour. Songo Mnara is about 2km south of Kilwa Kisiwani and this sheltered area is known as Sangarungu Harbour. Within the Kilwa ria dense mangrove-lined waterways are widespread and separate the islands from the mainland and each other.

Geomorphology has thus been kind to Kilwa providing an extensive complex of accessible and sheltered anchorages as well as varied natural resources. On the ocean side the exposed coast exhibits limestone cliffs with a wave-cut platform, and a lagoon with fringing reef to the south. Pollard (2008a) and Chittick (1974) have recorded trading evidence from Kilwa dating from $c$.7th century. It was part of the western Indian Ocean trading system that extended at least as far south as Chibuene, Madagascar and the Comoros Islands in the latter part of the first millennium (Fig. 1) (Sinclair et al., 2012). By the 12th-13th centuries, Kilwa was considered an important port-of-call 
when Ibn al-Mujawir, writing in 1232/1233, described it as a staging point on the route from Aden to al-Qumr (Madagascar) (Trimingham, 1975: 127-8). Excavations by Chittick (1974: 237-8) identified an increase in wealth in the port at that time, with the appearance of stone buildings and industrial activity. It was identified as an intermediate port en route between Aden and the Sofala region, through which gold from the Zimbabwe plateau was channelled into the world maritime trading system (Sutton, 1998: 113; Horton and Middleton, 2000: 101). Kilwa took over the gold trade from Mogadishu in the 12th century, according to the Kilwa Chronicle, but it was not until the late 13th-14th century that it secured a virtual monopoly, and with it imposing commercial and religious buildings (Freeman-Grenville, 1962: 91-2).

Much land-based archaeological research has been carried out on Kilwa and its hinterland, which has helped to define the city-state, its physical structure and political economy during the second millennium. The maritime foundation of Kilwa's importance, however, suggests that a broader view of its setting and trading operations might be obtained by extending archaeological work into the inter-tidal and subtidal zones. In the former respect, coastal and inter-tidal surveys have been conducted by Pollard (2008a; 2008b; 2011; Pollard et al., 2012), which defined maritime features such as causeways, harbour structures and industrial activity. The subtidal zone remains to be explored from an archaeological perspective, although there are some known wrecks and underwater anomalies, such as fishermen's fasteners/fouls or obstructions. Most of the recorded wrecks are of 20th-century date, and have been discovered by amateur sports divers, professional salvage companies or are listed by the United Kingdom Hydrographic Office (UKHO) (Table 1). Only one of these, that at Kisimani Mafia some $60 \mathrm{~km}$ north of Kilwa, potentially relates to the Medieval period (Jeffery and Parthesius, 2012).The distribution of the sites (Fig. 2) reflects the main ports on this stretch of the Swahili coast, namely Kwale-Kisiju, Mafia-Rufiji Delta, Kilwa, and Lindi Bay. This may merely reflect the current high level of activity in these areas that has brought wrecks and other obstructions to the notice of seamen. However, the concentration of past traffic would also raise the chance of shipwreck on the approaches to harbours, and particularly so for vessels under sail on coral limestone coasts with offshore fringing reefs when wind strength and direction cannot always be relied upon. In this study attention is concentrated on Kilwa in the two environs that potentially offer the greatest danger to shipping, the reefs that mark the harbour approach, and the port itself.

\section{Jiwe la Jahazi site}

In the first of these contexts, in 2004, Pollard recorded an area of black basalt, an exotic rock on the limestone coast, on the inter-tidal zone on the east coast of Kilwa Kisiwani in the area of Mvinje near a 'dhow-shaped' coral limestone islet called the Jiwe la Jahazi (Fig. 2) (Pollard, 2008b: 110). This site lies on the fringing reef a little over $1 \mathrm{~km}$ south of the entrance to Kilwa Kisiwani Harbour, 
between two reef-coral causeways. Local fishermen have a legend about the islet being a ship attacking Kilwa that was turned to stone, while the basalt on the foreshore marks the weapons of the invaders. In practice, the basalt would appear to be the ballast of a ship that had run aground on the reef. In 2015, the distribution of artefacts visible on the surface of the site was recorded by Trimble Geoexplorer GPS (Figs. 3 to 5).

The basalt at Jiwe la Jahazi consists of subangular to subrounded small boulders and cobbles concentrated on the seaward edge of the sharp limestone bedrock that forms rock pools up to $0.5 \mathrm{~m}$ deep in which the black stones lie. The basalt is dispersed amongst the rock pools but is concentrated in an area $60 \mathrm{~m}$ NW-SE by $30 \mathrm{~m}$ NE-SW. Some of the basalt shows white quartz veins and other parts the quartz has weathered green and furthermore there is red oxidation. Measurement of the longest dimension of the basalt blocks gives a range in size from 0.16 to $0.35 \mathrm{~m}$. Wave transportation has resulted in some sorting of the basalt; stones becoming smaller landward presumably with distance from the point of deposition.

Further search of the inter-tidal zone revealed an area of coarse-grained very hard orange sandstone that weathers to a yellow brown: it lies $50 \mathrm{~m}$ to the south-west of the basalt and extends from the landward edge of the spikey reef crest into the lagoon (Fig. 4-5). The sandstone is another dispersion amongst the lagoon but is concentrated in an area $90 \mathrm{~m} \mathrm{NW-SE}$ by $30 \mathrm{~m} \mathrm{NE-SW}$. The dispersion suggests carriage of lower density sandstone further inland than the basalt or that the original point of deposition was more towards the landward edge of the reef crest. The large cobble sandstone boulders vary in size from $0.36 \times 0.29 \times 0.33 \mathrm{~m}$ to $0.16 \times 0.11 \times 0.90 \mathrm{~m}$, and are angular to subangular, probably reflecting breaking along their bedding.

There were four basalt stones and one sandstone around the Jiwe la Jahazi that could not have been moved from the site by wave action due to the landward direction of dispersal of the artefacts across the reef. Therefore, they were probably brought there by fishermen to weigh down fish-trap baskets, left at low water and retrieved during the following low tide. Other exotic rocks found around the wreck-site were intrusive igneous, probably granite, and metamorphic, probably quartzite (Fig. 5). The granite is very hard, dense, with crystals $1-2 \mathrm{~mm}$ of pink, black and lightgrey colours. Other loose rock at the wreck-site is white quartz, flattish on the two widest sides, so probably from a vein. Quartz is also found in occasional nodules in the limestone, and is probably local with fishermen using them as hammer stones for opening shellfish.

The distribution of the pottery clearly conforms to the landward edge of the basalt reflecting its lighter density and hence its carriage further landward, including well into the lagoon (Fig. 4). Although rounded by being in the wave zone, the relatively thick (up to $30 \mathrm{~mm}$ ) and coarse red pottery includes flat bases and thickened rim, incised and moulded bands and one has possible traces of a clear slip on the inner surface (Fig. 6). Similar pot described as a storage jar from 
southern Iran has been recorded at Manda in Lamu Archipelago, Unguja Ukuu on Zanzibar, Sohar in Oman, and Siraf in The Gulf dated to the late-8th-10th century (Chittick, 1984: 84-91; Juma, 2004: 113-7; Priestman 2013: 474-6).

\section{Discussion}

The dispersion of basalt ballast indicates that either the hull split open and the ballast fell out signifying a shipwreck, or the ballast was thrown overboard to allow the ship to float off the reef producing a material dump. The pottery is clearly related to the basalt as opposed to the nearby sandstone ballast due to it being directly landward of the basalt where wave-energy over the reef would have carried and deposited in the lagoon. The distribution of the sandstone suggests a second shipwreck or grounding event, as most stones seem to have been carried directly landward longitudinally to the low water mark and reef crest independently of the basalt dispersion. The concentration of sandstone suggests that this vessel appears to have lost its ballast on the landward side of the reef crest perhaps due to a higher tide allowing it to reach further landward, it was leaving the lagoon for the open sea when it got into trouble or it was a lighter vessel that was carried further by waves before breaking apart. However, it cannot be ruled out that the dispersion represents carriage of lower density sandstone further inland from a single wreck-site, the ship having been ballasted with both basalt and sandstone, the basalt having been lost first before the boat was carried a further $50 \mathrm{~m}$ and finally torn apart losing the rest of its ballast. The combination of different ballast types is possible if a vessel trades in diverse locations, as a tramp ship would, loading basalt in one area of trade and sandstone in another (McGrail, 1989: 353). Assuming the sandstone signifies a separate deposition event to the basalt and pottery, the present evidence does not support an ocean-going vessel due to sandstone being found naturally within the harbour and may have been a local vessel gathering produce from the east coast such as reef coral, lime and fish for market at Kilwa Kisiwani port.

In the case of the exotic basalt, the presence of pottery, in part intermixed with the basalt but largely present as a landward tail as might be expected from a density perspective, adds credence to its interpretation of the basalt site as a shipwreck (although it is possible that broken pottery, especially heavy pottery, was reused as ballast). Furthermore, the ballast does not lie in an expected location for an ocean-going trading vessel, which would be expected to have sailed to the commercial port within Kilwa Kisiwani Harbour. Therefore, it is likely that it accidently struck the reef approaching the harbour. An ocean-going vessel approaching Kilwa would not deliberately sail over the sharp-limestone reef, so that the basalt distribution defines a ship striking the reef. Although, without any hull structure, it is not certain that the vessel(s) were not refloated following discarding ballast, this is considered very unlikely due to the sharpness of the limestone enclosing the rock pools on a reef crest $60 \mathrm{~m}$ wide, and the large amount of ballast stone on the reef. The sewn 
hulls of the late 8th-10th-century vessels in the western Indian Ocean were designed to flex going over shallow reefs and sand bars but the sharpness of the coral limestone at the Jiwe la Jahazi would have caused catastrophic damage to the vessel as it would have been carried across the reef by waves (seen by the dispersal of the basalt in Fig. 5). Finally, there is the oral tradition told on Kilwa Kisiwani of the shipwreck at Jiwe la Jahazi supporting a wrecking event.

The broad conclusion that can be drawn from the oral tradition of a shipwreck, the location in a sharp-limestone reef crest environment, late 8th -10th-century AD pottery, and basalt ballast is that of a wreck of a vessel carrying imported goods from the Gulf. The pottery, also found at Siraf and Sohar, correlates with the description by Al-Masudi of Persian and Omani merchants sailing the east African coast $c .10$ th-century. The ballast deposition of sandstone is probably an indication of a separate shipwreck or a grounding event due to the homogeneity of the area, distinct from the basalt and pottery area, and therefore the Jiwe la Jahazi was a dangerous zone for ships approaching Kilwa Kisiwani Harbour.

\section{Geophysical and diving surveys}

In an effort to investigate further the archaeology of the Jiwe la Jahazi site, other sections of the east coast including Msangamla, and Kilwa Kisiwani Port, surveys of the subtidal zone were carried out in February 2014. A geophysical survey was conducted using a SwathPlus 468kHz sidescan sonar, attached to a motor boat hired from the Tanzania Antiquities offices in Kilwa Masoko, in conjunction with a TSS DMS205 motion reference unit, sound velocity probe, Vector Hemisphere GPS and Topcon RTK dGPS. SCUBA diving surveys then took place, largely in 2015, to groundtruth and investigate in detail the possible cultural material highlighted. Diving was restricted to anomalies at less than $20 \mathrm{~m}$ depth for safety reasons. A selection of anomalies was investigated from outside the harbour and within the harbour to gather a wide variety of environments to examine preservation and distinguish natural from cultural features. A circular search pattern with two divers was used for anomalies. Other areas of potential interest were investigated with a swim line search using three to four divers.

The search along the ocean edge off the fringing reef between Causeways III and IV (Fig. 4) was undertaken to check on the possible presence of other material related to the Jiwe la Jahazi site. Nothing of significance was found, however, which is not unexpected due to coral-reef growth compared with the limestone bedrock of the reef crest and lagoon.

The majority of dives were performed within the harbour environment. While a haven from wind and waves might appear less dangerous to shipping, in practice, the high density of traffic, the possibility of collisions, the occurrence of squalls, misloading of ships, and abandonment of boats that were no longer seaworthy, all increase the likelihood of wrecks within the broad harbour and its principal port areas. One anomaly off Kilwa Kisiwani Port revealed an artefact dispersion on the 
seabed around $100 \mathrm{~m}$ from the low water mark that included a medieval stone anchor, local pottery, and imported pottery from south-west Asia (Fig. 7). The site is gently dipping covering about 1-1.5 m over the $100 \mathrm{~m}^{2}$ area. In 2015, a Tritech Starfish 990F sidescan sonar at a frequency of $900 \mathrm{kHz}$ and a sonar range of $20 \mathrm{~m}$ was used over this site to get a clearer picture of the environment and anomalies. The dive site at Kilwa Kisiwani Port is up to $10 \mathrm{~m}$ deep and presented some challenges in that underwater visibility was often no more than $1 \mathrm{~m}$. At low tide a strong current developed and the water appeared more saline making the divers more buoyant.

\section{Kilwa Kisiwani Port anchorage}

There is considerable evidence to show that Kilwa Kisiwani Port was important commercially by the 11th century AD. That is particularly displayed in the midden cliff face and eroded materials on the beach below which reveals large amounts of local and imported pottery, slag, spindle whorls, coins, beads, and bone indicating industrial and maritime activity in the first half of the second millennium (Pollard, 2008a: 93-4). Major stone building periods occurred from around 14th to 15th century including a mosque, sea walls and wells (Pollard, 2008a: 100-1).

Presently, Kilwa Kisiwani Port remains the main landing area for the modern village. The shortest inter-tidal zone is at Bandari Hussein (port of Hussein) at the 14th-15th-century Omani Quay. Bandari Hussein was the most heavily used area of the port when larger vessels visited. This is supported by the presence of the Omani Quay and the depth of the midden cliff, which is at its maximum in this area, indicating both a greater and longer period of activity. To the west of Bandari Hussein is the Malindi area named after the 15th-century mosque, which overlooks this landing area. West of Malindi is Gerezani named after the Portuguese and Omani Fort (Gereza) that dominates Kilwa Kisiwani Harbour. Local boats usually anchor on either side of Malindi. Gerezani is the industrial area of the port, being the location for boatbuilding and repair and the storage of fishing equipment. Bandari Hussein is the most popular area for waiting and boarding boats today as it has the shortest inter-tidal zone and the substrate is much firmer at low tide than at Gerezani. To the west of the Omani Quay are stone steps leading up the midden cliff. These have recently been modified, along with sea wall protection for the eroding cliff, but are probably formerly associated with boarding vessels at this location. Bandari Hussein is the more commercial part of the port: dhows regularly transport people and goods from here to Kikone Landing Place at Kilwa Masoko (Pollard, 2008a: 218). Locals consider that 'Fundi' Hussein was a blacksmith, though it was unclear when he lived as no one in the village knew him.

To the east of Bandari Hussein the land rises to Shuleni named after the modern school. At the high water mark here is a sea wall. The foreshore is bedrock with mangrove patches: the rockiness of the foreshore makes it unsuitable for landing boats. The pier is modern and built for use by tourists. East of pier is the Narani area, named after a navigation tower that used to be sited 
on the cliff-edge. Here was once the stone anchor, known locally as 'the Sultan's bedpost', recorded by Chittick (1974: 414), but which unfortunately had been moved landward by locals wanting to ornament their tourist café breaking the anchor in the process.

The positions of pottery artefacts on the seabed were plotted on the sidescan sonar of the underwater site undertaken in 2015 (Fig. 8, Table 2). An Indo-Arabian type of stone anchor, $1.88 \mathrm{~m}$ in length, was found within the dispersion (Fig. 9). The anchor has an orientation of 030/210 (SW/NE) tapering to the SW. Its SW end is more buried in the silty-sand substrate. It is of similar shape to that recorded by Chittick at Narani (Chittick, 1974: 414), but the newly discovered underwater anchor is about $0.65 \mathrm{~m}$ longer. It is damaged at the round hole, which may indicate how the anchor was lost. Chittick's anchor has two rectangular holes piercing the shank crossing each other orthogonally. In the underwater anchor one of the holes for the flukes is semi-circular and open on one side (as can be seen in the side view in Fig. 9).

The stone anchor was used as the main reference point for diving to determine the extent of the pottery dispersion and the following is a description of what was recorded on the seabed following cardinal and intermediate directions (Fig. 8). The pottery dispersion continues for $20 \mathrm{~m}$ to the anchor's north until the silty-sand substrate becomes mud where either the dispersion disappears under the mud or peters out. A denser dispersion of artefacts has been deposited to the east of the anchor where a combination of angular and rounded cobbles/small boulders, pottery and bones lies on the seabed. The maximum dimension of these boulders is $200-300 \mathrm{~mm}$. The stones are heavy basalt, similar to that recorded at the Jiwe la Jahazi site. This denser dispersion peters out at around $60 \mathrm{~m}$ east where there were only two more blocks of basalt and a pot sherd, and beyond $75 \mathrm{~m}$ there was mud with no sign of artefacts. To the south-east the artefacts peter out as a loose rounded coral substrate appears after $30 \mathrm{~m}$, and at $60 \mathrm{~m}$ only a single pot sherd was recorded. To the south there is a concentration of pot sherds among mud and pebbles for $30 \mathrm{~m}$, while the sediment becomes sandier with marine life increasing as the substrate gradually rises towards Bandari Hussein. To the north-west there is pottery on the seabed for $30 \mathrm{~m}$, after which the substrate becomes mud. The pot dispersion is dense to the west for up to $30 \mathrm{~m}$, but decreases in frequency for the next $30 \mathrm{~m}$ : it may continue further west. Further investigation of the denser dispersion of artefacts to the east discovered an artefact spread starting around $25 \mathrm{~m}$ (centred around $40 \mathrm{~m}$ ) north-east of the anchor covering $c .30 \mathrm{~m}^{2}$ (Fig. 7). This artefact spread is less than $0.5 \mathrm{~m}$ high on a stony seabed consisting of large amounts of pot, bone, shells, angular limestone, quartz, sandstone and basalt.

The seabed material included local and imported ceramics (Figs. 11 and 12, Table 2). Due to the potential damage that taking an artefact out of water generates, only a sample of the pottery on the seabed was removed to identify use, origin and dating. Almost all the artefacts were covered by corals and worm casts, probably the shell worm Dendropoma corallinaceus. The ceramics were 
repeatedly soaked in fresh water, cleaning each time between water changes, for a period of four months. Most materials observed were left in situ at the underwater site for better conservation and a future expedition with more conservation facilities.

Some sandy limestone slabs on the seabed stand out as different to the substrate, but their function is not immediately determined. They included, $14 \mathrm{~m}$ from the anchor, a rectangular slab, $0.44 \times 0.38 \times 0.11 \mathrm{~m}$, (No. 0 on Fig. 8 ), an oblong block, $0.70 \times 0.30 \times 0.18 \mathrm{~m}$, partly covered in the sandy substrate (No. 3 on Fig. 8), and a triangular block, with sides $0.38 \times 0.25 \times 0.20 \mathrm{~m}$ and a thickness varying from $0.10-0.20 \mathrm{~m}$, standing upright on the seabed. It is possible these blocks are ballast, but some appear to be dressed, and thus could be building stone or parts of composite anchors. Similar three blocks of stone were recorded near the low water mark and a further two were recorded landward nearer the midden cliff of Bandari Hussein reinforcing the possibility of their use as anchors (Pollard, 2008a: 107) (Fig. 7). It is possible they are stones from ruined buildings, reused as anchor weights but they may also have been brought by the vessels anchored in the harbour as they are similar to those recorded underwater. A distinctive triangular cone-shaped block $1.5 \mathrm{~m}$ in diameter and up to $1 \mathrm{~m}$ high was around $75 \mathrm{~m} \mathrm{SE}$ of the anchor. It may be a natural fossil coral but needs further investigation (No. 4 on Fig. 8).

\section{Discussion}

The artefact dispersion surrounding the stone anchor includes local and imported pottery varying in date from the 9th-17th century. This reflects a long period of use of the space off Kilwa Kisiwani Port as an anchorage. Pottery finds from the artefact spread north-east of the anchor range from the 13th-16th century. The presence of sandstone and basalt on the seabed is not natural in this silty-sand environment and, similarly to the Jiwe la Jahazi site, is expected to be ships ballast. The stone anchor marks an anchorage off Kilwa Kisiwani Port, but, starting at $25 \mathrm{~m}$ distance from the ballast concentration, it cannot be definitely linked to the artefact spread. However, the 13th16th-century pottery and bones in this location is probably associated with the basalt and sandstone though it cannot be discounted that later artefacts have been dropped in this area or moved by currents within the harbour environment. In the case of Kilwa Kisiwani Port artefact spread, ballast and other stone artefacts are unlikely to be deliberately dumped close inshore in a principal navigation and administered harbour area, especially when ballast stone is often reusable as building stone (Chittick, 1984: 45, 198). The combination of the artefacts and ballast within a concentrated area is likely to be indicative of a shipwreck especially as the assemblage consists of 'light' incense burners, bones and complete bowls that would not have been normal ballast choices. Therefore, the sinking of a ship in Kilwa Kisiwani Port anchorage is the preferred explanation. Confirmation of a shipwreck would, however, be dependent upon further investigation at the site 
especially through test excavation of the silt substrate to search for further artefacts or, indeed, shipstructure remains.

\section{Indian Ocean medieval trade}

On the assumption that these are indeed shipwrecks, they are the first to be found in the Kilwa area compatible with a medieval dating, and add to the emerging evidence of non-European shipwrecks coming from around the Indian Ocean. Their finding confirms expectations of wrecksites in particularly vulnerable positions for shipping, that on a reef-lined coast in the vicinity of a harbour entrance, and within the harbour itself. Unfortunately, the environments in which they are found display significant post-depositional transformation processes over the subsequent centuries. The inter-tidal wreck(s) of Jiwe la Jahazi would have experienced salvage from inhabitants of Kilwa Kisiwani, marine and biological degradation, and gradual landward progradation of any surviving artefacts. The subtidal harbour wreck is subjected to a strong current particularly at low tide as well as siltation and organic decay processes.

The widespread presence of igneous basalt is of considerable interest as it has to have been imported to this sedimentary coast. Apart from the Jiwe la Jahazi site, there are two further areas of basalt recorded on the reef crest around Kilwa, both in the vicinity of causeway features: one is at Kivurugu near the westernmost point of Songo Mnara, and the other at Matuso at the northern entrance to Kilwa Kisiwani Harbour (Fig. 2). The Matuso basalt extends for c.50 m, but neither the Kivurugu nor Matuso basalt distribution has been investigated to see if they are associated with other artefacts that could be dated. Pollard (2008b: 109-10) has argued that the inevitable shipwrecks might have precipitated the need to mark the reef edge by building the reef-coral causeways that themselves support the growth of mangroves marking the reef edge and the way into the harbours of Kilwa Kisiwani and Sangarungu.

Finds of basalt are not confined to Kilwa. The same stone has been recorded further south on the limestone foreshore at Mtamba in the Kiswere area, and Patumla in Ruvu Bay (Fig. 2). Both locations are again landing places in areas of reef-coral causeways. However, the fragments are too few to be ascribed to a shipwreck and may have been ballast deliberately unloaded.

Further south again, on Mozambique Island, a large basalt block lies in the inter-tidal zone the base of the cliff below the 16th-century Portuguese Fort São Sebastiã. The block is about 1m long and, as it is dressed, it could have been cargo from a shipwreck (Fig. 13). Other smaller basalt boulders can be seen in the walls below the Chapel of Nossa Senhora de Baluarte, built in 1522. As this area of the island has no landing place and is backed by a steep cliff, the blocks probably came from a wreck and were reused for the wall. Black basalt is also found in a pier on the landward side of the island. 
Other writers have noted basalt far from its geological sources: for example, boulders of olivine basalt were also incorporated in a wall dated to $c .1025-1050 \mathrm{AD}$ at Manda in the Lamu Archipelago (Chittick, 1984: 45, 198). Radimilahy (1998: 180, 194) recorded a triangular piece of basalt, perhaps used as a net weight, from the $c .9$ th-10th century AD at Mahilaka on Madagascar. It would seem that the tradition of basalt as ballast must go back to the Classical period in the western Indian Ocean as it was found on the Red Sea Indian Ocean coast ports of Myos Hormos and Berenike (Tomber, 2012: 205).

Other rocks, exotic to Kilwa, have been recorded along the reef including granite, quartzite and gneiss, but all in very small quantities. The sandstone at Jiwe la Jahazi may derive from beyond the region, but that rock is not entirely foreign to the Swahili coast of southern Tanzania, although the principal petrology of the wreck-site is limestone (coral rag). Basalt is most predominant, and indicates that ships trading with Kilwa visited areas of basalt geology. However, the possibilities are widely dispersed and include the Comoro Islands to the south-east, the Deccan Plateau of India to the east, and the Arabian Peninsula to the north. Basalt in Red Sea ports has been interpreted as coming from the Hadramawt. Chittick (1974: 415; 1984: 45, 198) also attributed the finds of basalt at Manda and Kilwa to ballast from Arabia. As far as is known, however, there is no scientific attribution to this claim. In contrast, some preliminary chemical analysis of the Jiwe la Jahazi basalt indicates a close similarity with Comoros basalt, but no analysis has been done to exclude other sources.

As previously noted, we must be cautious when interpreting the underlying cause of the basalt finds. In particular, locations will not always equate to wreck-sites. While a shipwreck, or a grounding event, would be the logical explanation for ballast found on offshore reefs, such as Jiwe la Jahazi, and rocky or cliff coastlines, its original function needs to be considered in more detail for other contexts. The whole purpose of basalt is to trim the ship in the absence of sufficient cargo weight. Thus, when taking on cargo heavy cargo, such as mangrove wood, salt or iron goods, a lightly loaded incoming vessel would discharge excess ballast at the landing site. Ballast found at ports, would be compatible with trade in a high-value, low-weight commodities, such as frankincense, beads and jewellery, or textiles and garments. Any vessel that was not fully loaded would also require some ballasting, so that imported pottery could be found in combination with ballast, as appears to be the case with the Kilwa sites. Thus, context is all-important in the explanation of basalt and other exotic ballasting materials.

It is possible to speculate on the content and direction of Kilwa's trade insofar as ships wrecked on the reef are more likely to be inward-bound as vessels leaving the harbour would be expected to await favourable sailing conditions, while those arriving must accept whatever conditions prevailed. Prestholdt (1998) has attested to the levels of adornment and material 
consumption of the wealthy populations of the Swahili city-states, much of which would involve imports of lighter weight commodities, such as clothing materials, beads and other jewellery, precious metals, porcelain, incense and beauty products. Such would probably require ballast as might luxury foodstuffs such as dates, oils and spices. In contrast, the likely exports of mangrove wood, salt, lime, worked iron and ivory are much less likely to have needed ballasting. As for gold from Sofala, little is known of arrangements for its transfer via Kilwa on its journey north, although, given its value, the physical quantities shipped in any vessel would not be expected to be large.

Ballast material can clearly help identify landing sites for ships around Kilwa. For instance, Rwayo on the mainland in the Mgongo area exhibits a mangrove whelk midden on a sand spit that can be dated from the pottery from the 14th-16th century (Fig. 2). The midden contains some basalt on the surface along with iron dhow nails, and suggests a vessel landed here, possibly to collect salt or mangroves as these are nearby resources, and perhaps degraded at the site. Furthermore, the mainland to the south at Somanilo in the Sanga area was an important 15th-16th-century port: it, too, displays basalt in a 14th-16th-century context on the cliff overlooking the port. Chittick (1974: 415) also recorded a large $(70 \times 50 \times 35 \mathrm{~mm})$ piece of basalt on Kilwa Kisiwani, a stone that appeared to have been used for grinding. Unfortunately his description is unclear as to where or whether this was found in a stratified deposit.

No wood has been recorded at any of the ballast sites. It may be presumed that wood might have been salvaged: otherwise, the tidal and wave energy along the exposed inter-tidal zone would be expected to wash away such low-density material or, if fixed in situ, it is likely to have succumbed to worm or other biological attack over the centuries. Very little wood from ships was recorded during the survey of Kilwa: the most significant was a recent dhow mast that lay on the reef $1.5 \mathrm{~km}$ north-west of the Matuso ballast. The Kilwa Kisiwani Port shipwreck holds the prospect of physical remains of a vessel, with the possibility of preservation of wood beneath the surface of the mud and other substrate. The surface finds reported here provide encouragement to investigate this site more intensively by excavating below the surface. It is also intended to extend geophysical and diving searches over the whole Kilwa area and the southern approaches to Songo Mnara with the goal of discovering medieval shipwreck sites that might shed light on boat construction and sailing techniques and the inventories carried on the trading ships of the Swahili coast.

\section{Acknowledgements}

Fieldwork was funded by National Geographic Society (NGS) and British Institute in Eastern Africa (BIEA). Thanks are due to Drs Colin Breen and Rory Quinn (Ulster), Prof Paul Lane (Uppsala), Dr Seth Priestman (Edinburgh), John Kanyingi, Okeny Charles Kinyera, Agathe 
Dupeyron, Prof. Ambreena Manji and Dr Joost Fontein (BIEA), Dr Stephanie Wynne-Jones (York/Uppsala), Dr Stéphane Pradines (Aga Khan), Christopher Thornton (NGS), Prof Monica Smith (UCLA), Joyce Kam (Brandenburg University of Technology/Helwan), Rahma Mpangala (Dar es Salaam) and Dr Bill Jeffery (Guam) for supporting the research. The Department of Antiquities and Ministry of Natural Resources and Tourism issued fieldwork permits. Finally, the authors are grateful to the editor and two anonymous referees for their edits and comments.

\section{References}

ARDA, 1980, Division of Antiquities Annual Report for the Year 1976 and 1977. Dar es Salaam.

Bita, C., 2013, Ancient Afro-Asia links. Evidence from a maritime perspective. Journal of Indian Ocean Archaeology 9, 2012-13.

Bita, C., 2014, Ngomeni Shipwreck, Report and Future Plans. Underwater Archaeology Project Report. National Museums of Kenya, Mombasa.

Bita, C., 2015, The potential of underwater archaeology in Kenya: A short communication, in S. Tripati (ed.), Shipwrecks around the World: Revelations of the past, 486-510. New Delhi. Bita, C. and Tripati S., 2015, Historical period stone anchors from Mombasa, Kenya: Evidence of maritime contacts with Indian Ocean countries. Bulletin of the Australasian Institute for Maritime Archaeology 39, 84-91.

Bita, C. and Wanyama, P., 2007, Preliminary intertidal and underwater archaeological survey of Lamu archipelago. Research Report, Fort Jesus Museum, Mombasa.

Bita, C. and Wanyama, P., 2011, Archaeological impact assessment report for the proposed capital dredging works at Kilindini channel and second container terminal at Port Reitz in Mombasa County, CHIA Report, 9-43. National Museums of Kenya, Mombasa.

Breen, C and Lane, P, 2003, Archaeological Approaches to East Africa's changing Seascapes. World Archaeology 35, 469-89.

Chalmin, P., 1987, Trade and merchants: panorama of international commodity trading. London Chittick, N., 1974, Kilwa: An Islamic Trading City on the East African Coast. Nairobi.

Chittick, N., 1984, Manda: Excavations at an Island Port on the Kenya Coast. Nairobi.

Flecker, M., 2001, A ninth-century AD Arab/Persian or Indian shipwreck in Indonesia: first evidence for direct trade with China. World Archaeology 32, 335-54.

Forsythe, W., Quinn, R. and Breen, C., 2003, Subtidal archaeological investigations in Mombasa's Old Port, in P. Mitchell, A. Haour and J. Hobart (eds), Researching Africa's past: New Contributions from British Archaeologists, 133-8. Oxford.

Freeman-Grenville, G. P., 1962, The East African Coast: Selected documents from the first to earliest nineteenth century. Oxford. 
Garlake, P. and Garlake, M., 1964, Early Ship Engravings of the East African Coast. Tanzania Notes and Records 63, 197-206.

Gaur, A., Sundaresh. S. and Vora, K., 2008, Underwater Archaeology of Dwarka and Somnath, 2457. New Delhi.

Gilbert, E., 1998, The Mtepe: regional trade and late survival of sewn ships in East African waters. IJNA 27, 43-50.

Guinote, P., Frutuoso, E. and Lopes, A., 1998, Naufrágios e Outras Perdas de Carreira da Índia Portuguesa. Lisbon.

Horton, M. and Middleton, J., 2000, The Swahili: the Social Landscape of a Mercantile Society. Oxford.

Hourani, G., 1995, Arab Seafaring. New Jersey.

Ichumbaki, E., 2015, Maritime and Underwater Cultural Heritage of the United Republic of Tanzania: History, opportunities and future directions, in S. Tripati (ed.), Shipwrecks around the World: Revelations of the Past, 526-36. New Delhi.

Inghams, K., 1962, A History of East Africa. London.

Jeffery, B. and Parthesius, R., 2013, Maritime and Underwater Cultural heritage Initiatives in Tanzania and Mozambique. Journal of Maritime Archaeology 8, 153-78.

Juma, A., 2004, Unguja Ukuu on Zanzibar: An Archaeological Study of Early Urbanism. Uppsala.

Kirkman, J., 1964, Men and Monuments on the East African Coast. London.

Lane, P., 2005, Maritime Archaeology: A Prospective Research Avenue in Tanzania, in B.

Mapunda and P. Mswema (eds), Salvaging Tanzania's Cultural Heritage, 95-131. Dar es Salaam.

McConkey, M. and McErlean, T., 2007, Mombasa Island: A Maritime Perspective. International Journal of Historical Archaeology 11, 99-121.

McGrail, S., 1989, The shipment of traded goods and of ballast in antiquity. Oxford Journal of Archaeology 8, 353-8.

Patience, K., 2006, Shipwrecks and Salvage on the East African Coast. Bahrain.

Pedersen, R., 2008, The Byzantine-Aksumite period shipwreck at Black Assarca Island, Eritrea. Azania 43, 77-94.

Pollard, E., 2008a, The Archaeology of the Tanzanian Coastal Landscapes in the 6th to 15th Centuries $A D$. Cambridge.

Pollard, E. J. D., 2008b, Inter-tidal causeways and platforms of the thirteenth- to sixteenth-century city-state of Kilwa Kisiwani, Tanzania. IJNA 37, 98-114.

Pollard, E., 2011, Safeguarding Swahili Trade in the 14th and 15th Centuries: a Unique Navigational Complex in South-East Tanzania. World Archaeology 43, 458-77. 
Pollard, E., Fleisher, J. and Wynne-Jones, S., 2012, Beyond the stone town: maritime architecture at fourteenth-fifteenth century Songo Mnara, Tanzania. Journal of Maritime Archaeology 7, 43-62.

Prestholdt, J., 1998, As artistry permits and custom may ordain: the social fabric of the Swahili world circa 1450 to 1600. Northwestern University.

Priestman, S., 2013, A Quantitative Archaeological Analysis of Ceramic Exchange in the Persian Gulf and Western Indian Ocean, AD c.400 - 1275. Ph.D. Thesis, University of Southampton.

Radimilahy, C., 1998, Mahilaka: An archaeological investigation of an early town in northwestern Madagascar. Uppsala.

Quinn, R., Forsythe, W., Breen, C., Boland, D., Lane, P. and Lali, A., 2007, Process-based models for Port evolution and wreck site formation at Mombasa, Kenya. Journal of Archaeological Science 34, 1449-60.

Sinclair, P., Ekblom, A. and Wood, M., 2012, Trade and society on the south-east African coast in the later first millennium AD: the case of Chibuene. Antiquity 86, 723-37.

Souter, C., 1988, Stone anchors near Black Fort, Galle, Sri Lanka. IJNA 27, 331-42.

Sprenger, A., 1841, El-Mas 'údi's Historical Encyclopedia entitled Meadows of Gold and Mines of Gems. London.

Sutton, J., 1998, Kilwa. Azania 33, 113-69.

Tomalin, V., Selvakumar, V., Nair, M. and Gopi, P., 2004, The Thaikkal-Kadakkarappally Boat: an Archaeological Example of medieval Shipbuilding in the Western Indian Ocean, IJNA 33, 253-63.

Tomber, R., 2012, From the Roman Red Sea to beyond the Empire: Egyptian ports and their trading partners. British Museum Studies in Ancient Egypt and Sudan 18, 201-15.

Trimingham, J., 1975, The Arab Geographers, in N. Chittick and R. Rotberg, (eds), East Africa and the Orient, 115-46. London.

Tripati, S., 2003, Anchors from Goa waters, Central West Coast of India: Remains of Goa's Overseas trade contacts with Arabian countries and Portugal. Bulletin of the Australasian Institute for Maritime Archaeology 27, 97-106.

Tripati, S., Gaur, A. and Bandodker, S., 1998, Historical period stone anchors from Vijaydurg on the west coast of India. Bulletin of the Australian Institute for Maritime Archaeology 22, 18.

Vosmer, T., 1999, Indo-Arabian stone anchors in the western Indian Ocean and Arabian Sea. Arabian Archaeology and Epigraphy 10, 248-63.

Whitehouse, D., 1970, Excavations at Siraf. Third Interim Report. Iran 8, 1-17. 


\section{Captions}

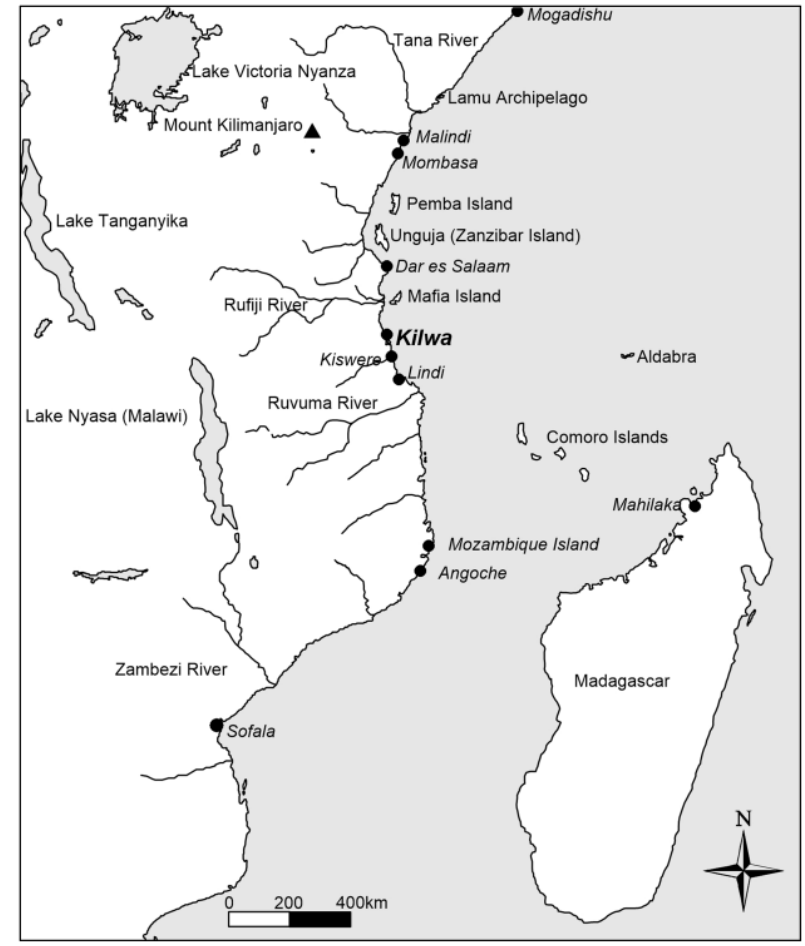

Figure 1. Location of Kilwa along the east African coast. (E. Pollard)

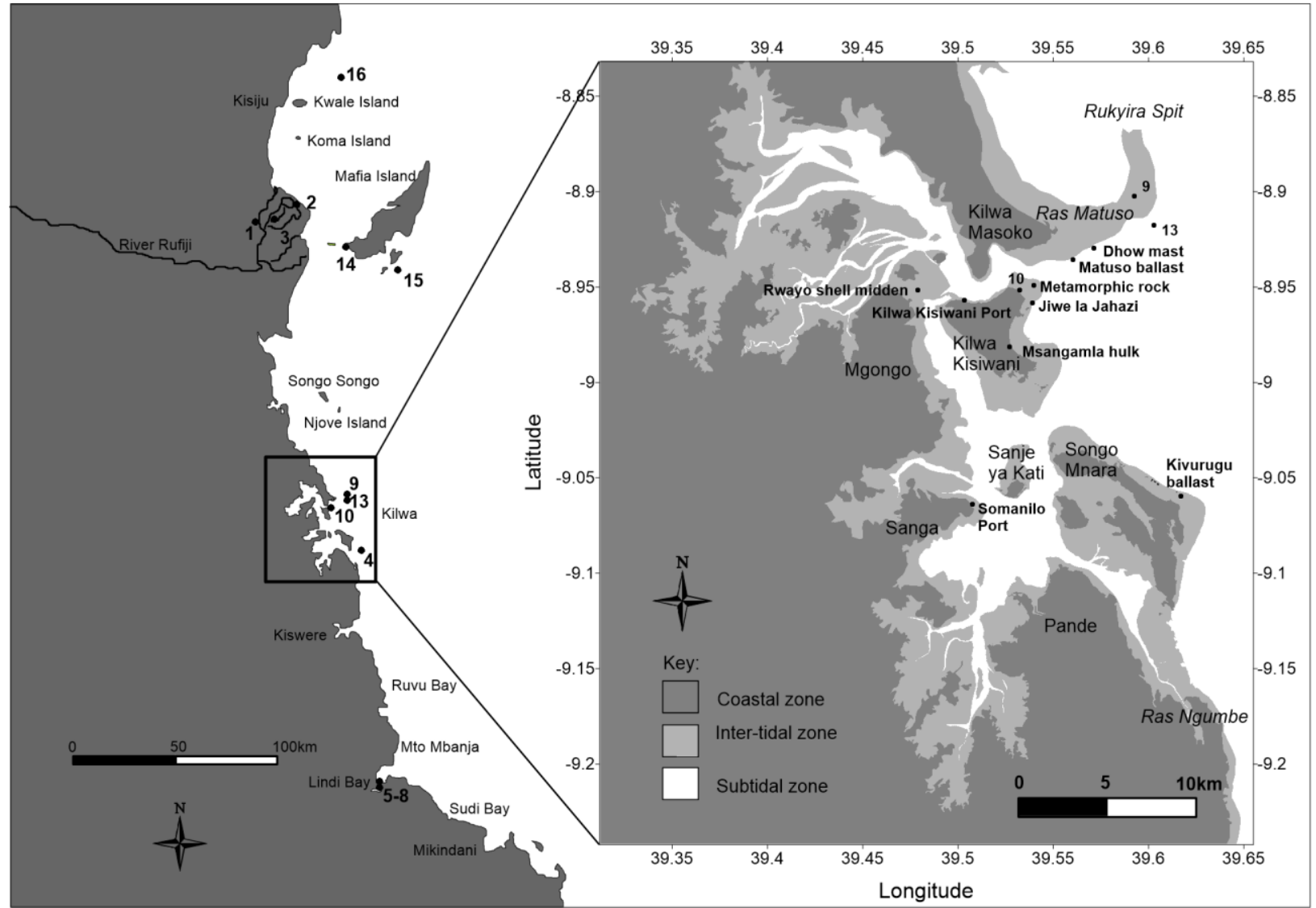


Figure 2. Recorded shipwrecks, hulks, obstructions, anchors, fouls and anomalies surrounding Kilwa where co-ordinates are known, Numbers refer to Table 1; inset: sites recorded in survey around Kilwa ria. (E. Pollard)

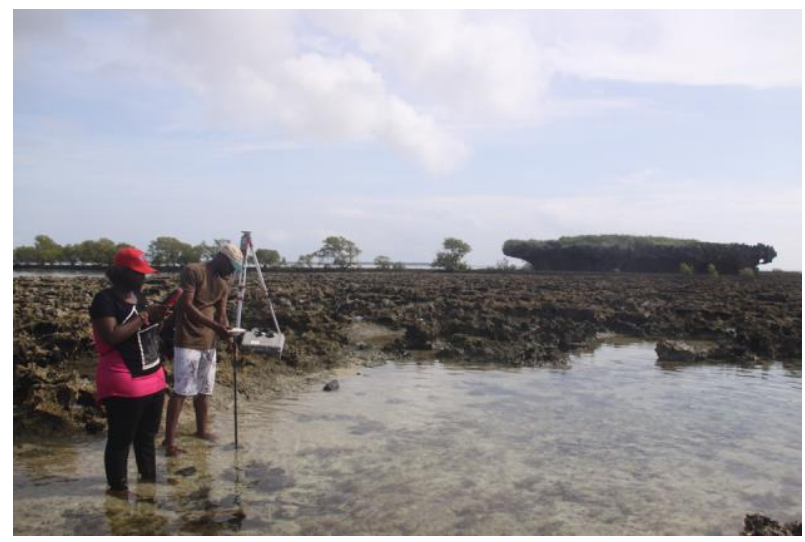

Figure 3. Recording artefacts on the reef crest with the Jiwe la Jahazi islet in the background. (E. Pollard)

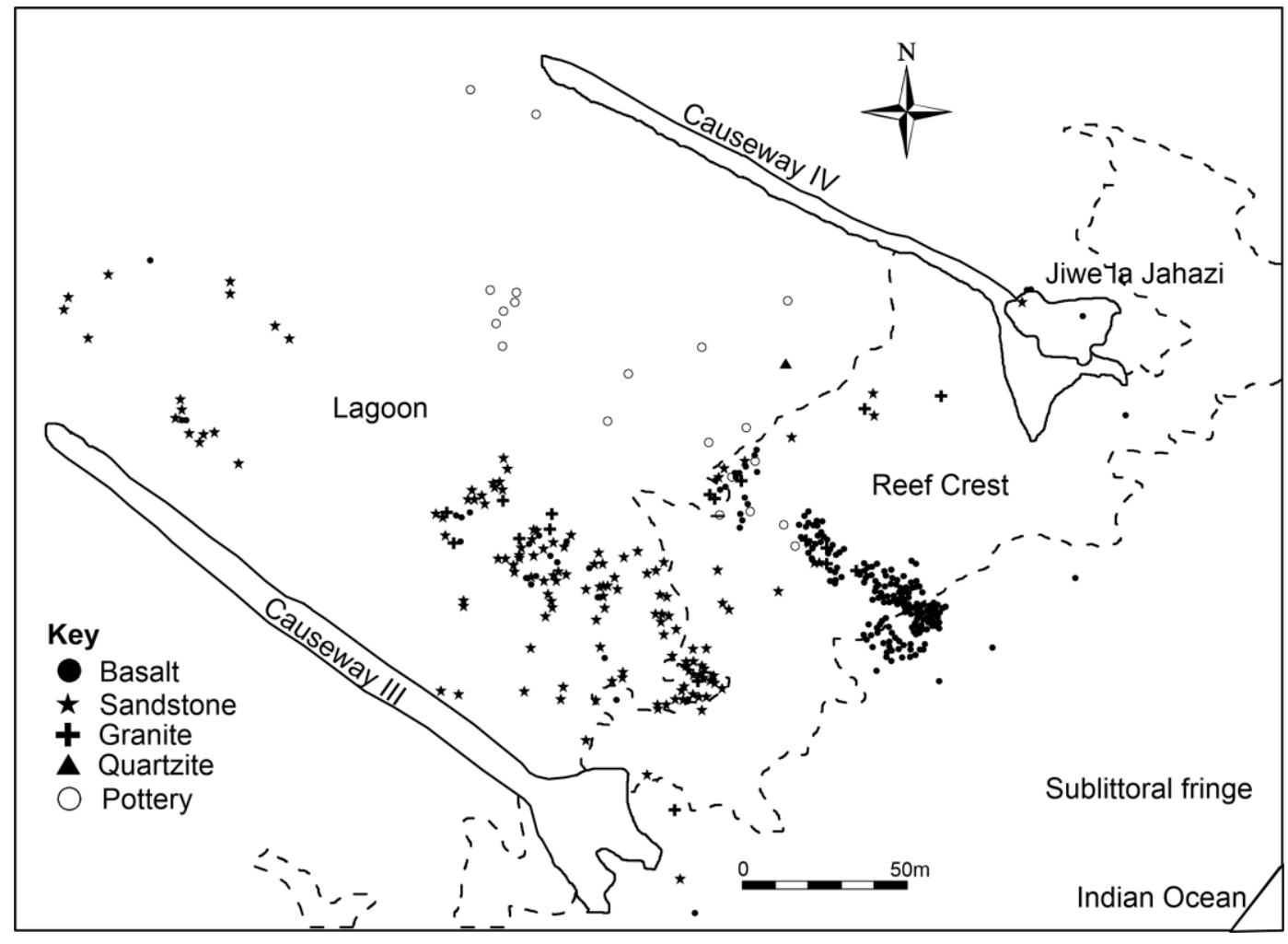

Figure 4. Distribution of materials at Jiwe la Jahazi shipwreck site. (E. Pollard)

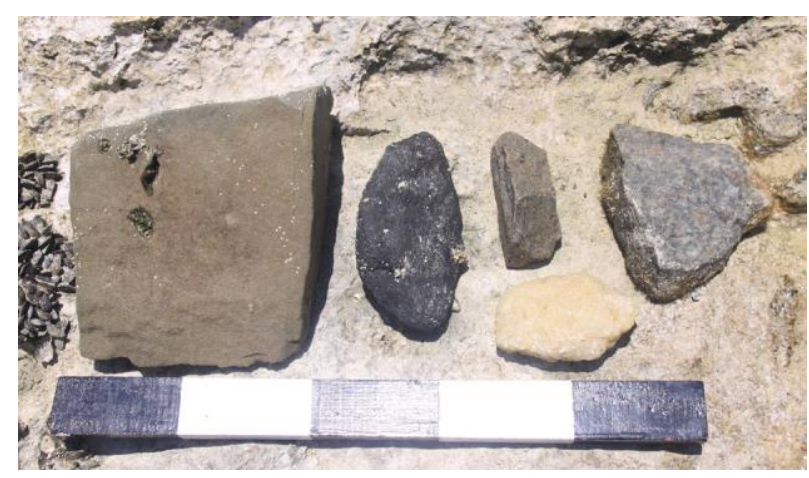


Figure 5. Stones from the Jiwe la Jahazi site. Top row from left: sandstone, basalt, granite and quartzite; bottom row quartz, scale 0.5 m. (E. Pollard)
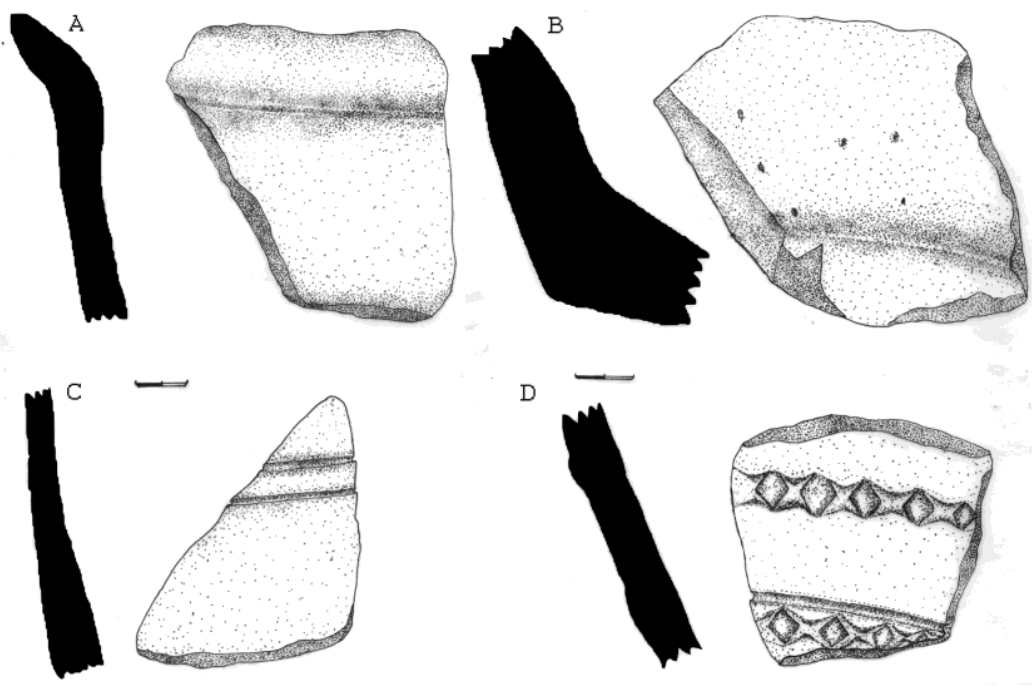

Figure 6. Imported pottery from the Jiwe la Jahazi site. (E. Ichumbaki and S. Kilindo)

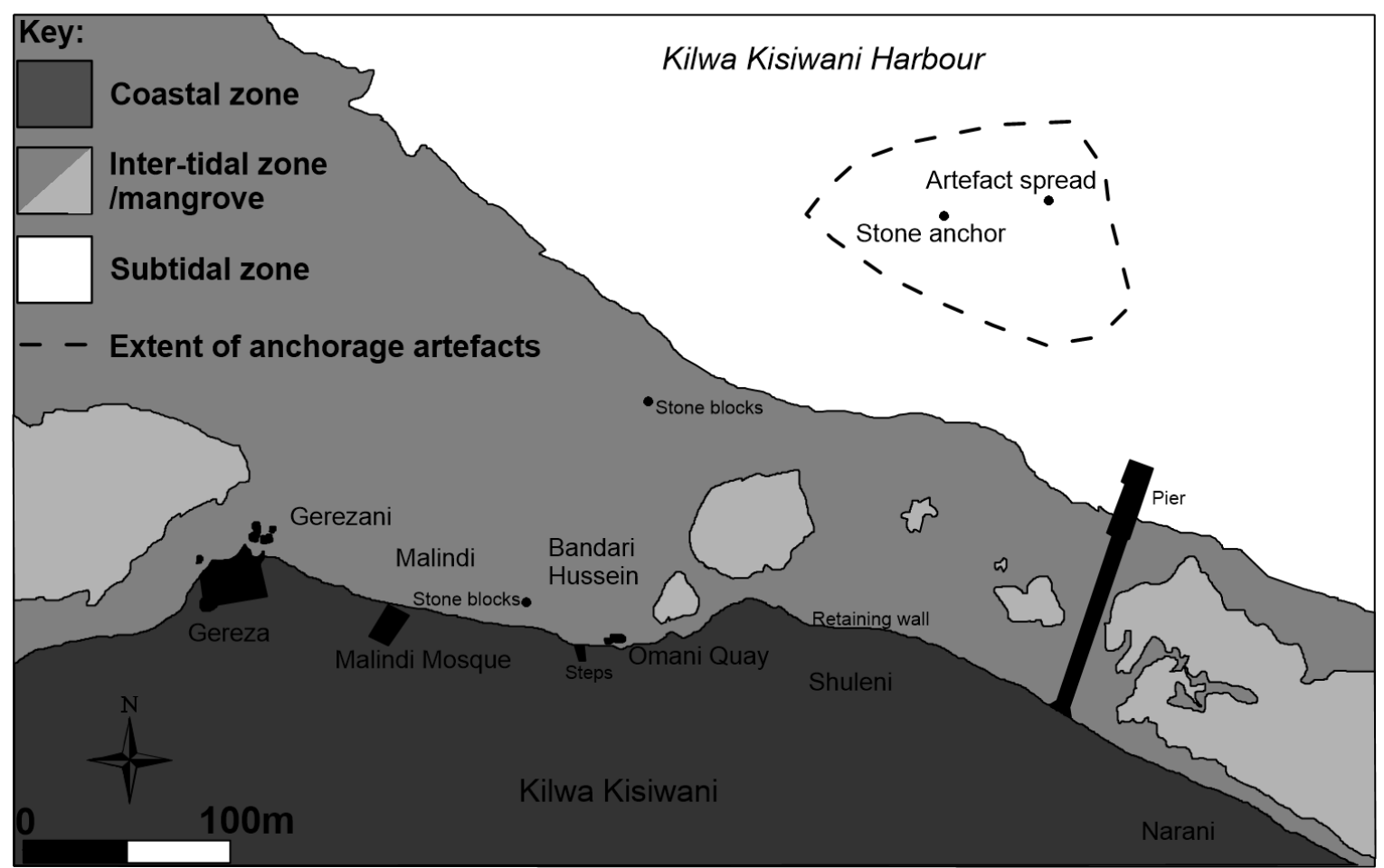

Figure 7. Kilwa Kisiwani Port showing the approximate extent of material recorded in 2015. (E. Pollard) 


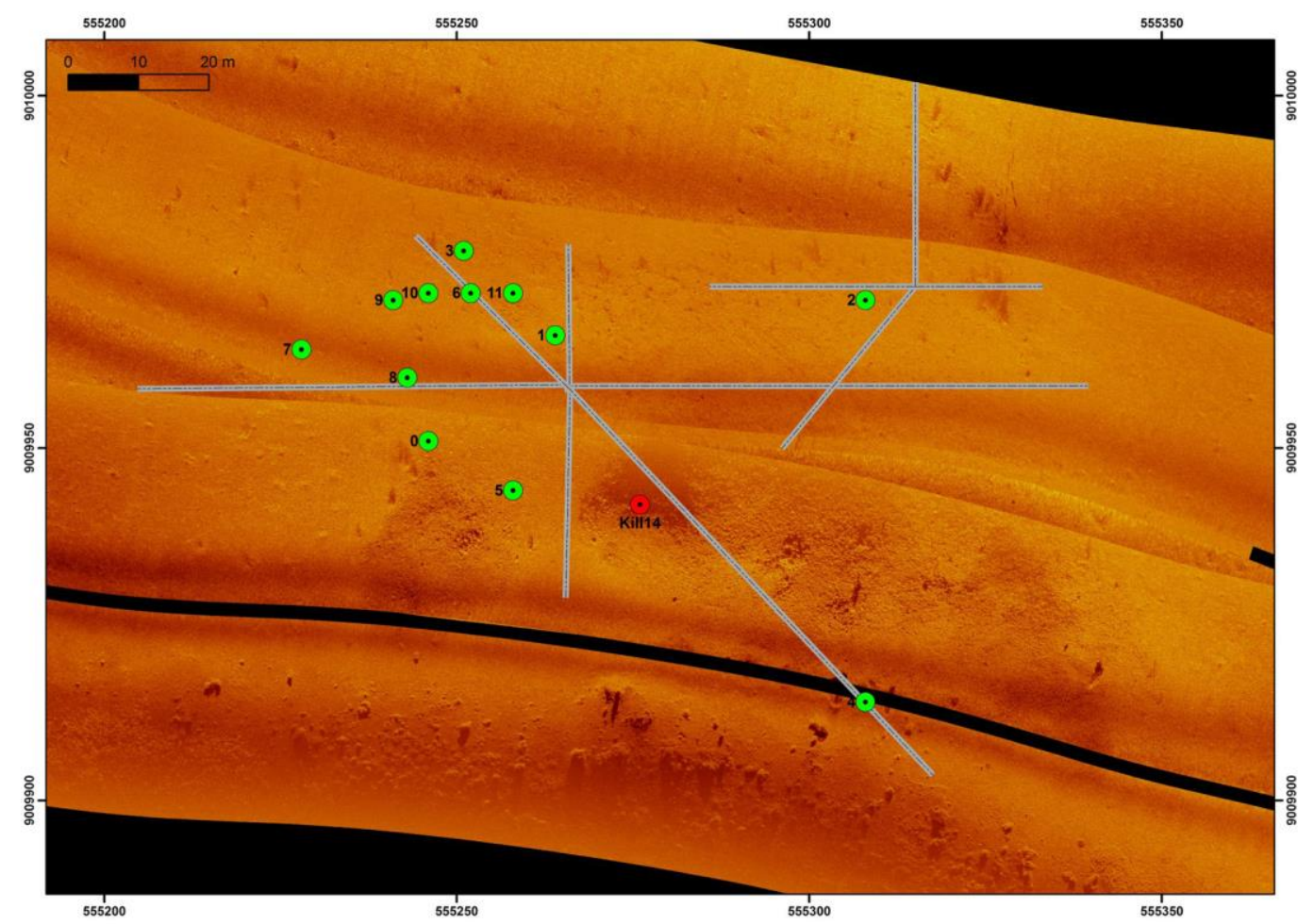

Figure 8. Sidescan sonar image of the Kilwa Kisiwani Port anchorage site showing the target, dive directions and extent of material recorded. (R. Bates)

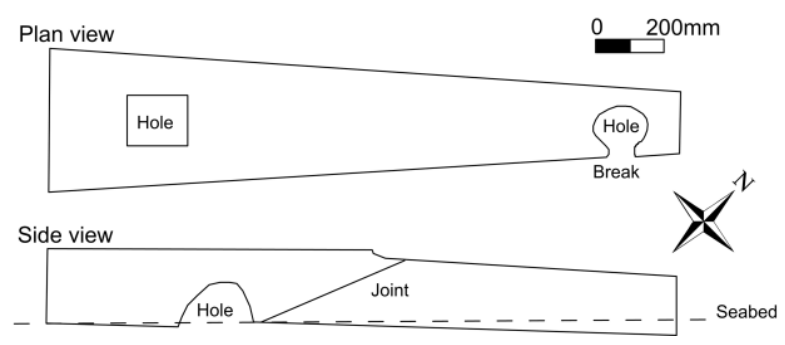

Figure 9. The stone anchor shank drawn from measurements taken under water. (E. Pollard)

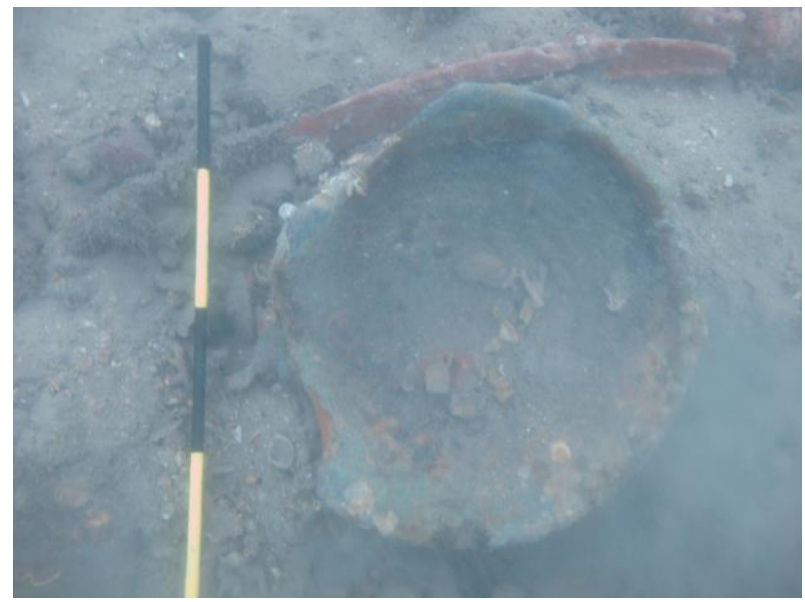

Figure 10. An Islamic monochrome vessel and large animal bone in the artefact spread on the seabed. Scale shows $0.1 \mathrm{~m}$ segments. (R. Bates) 

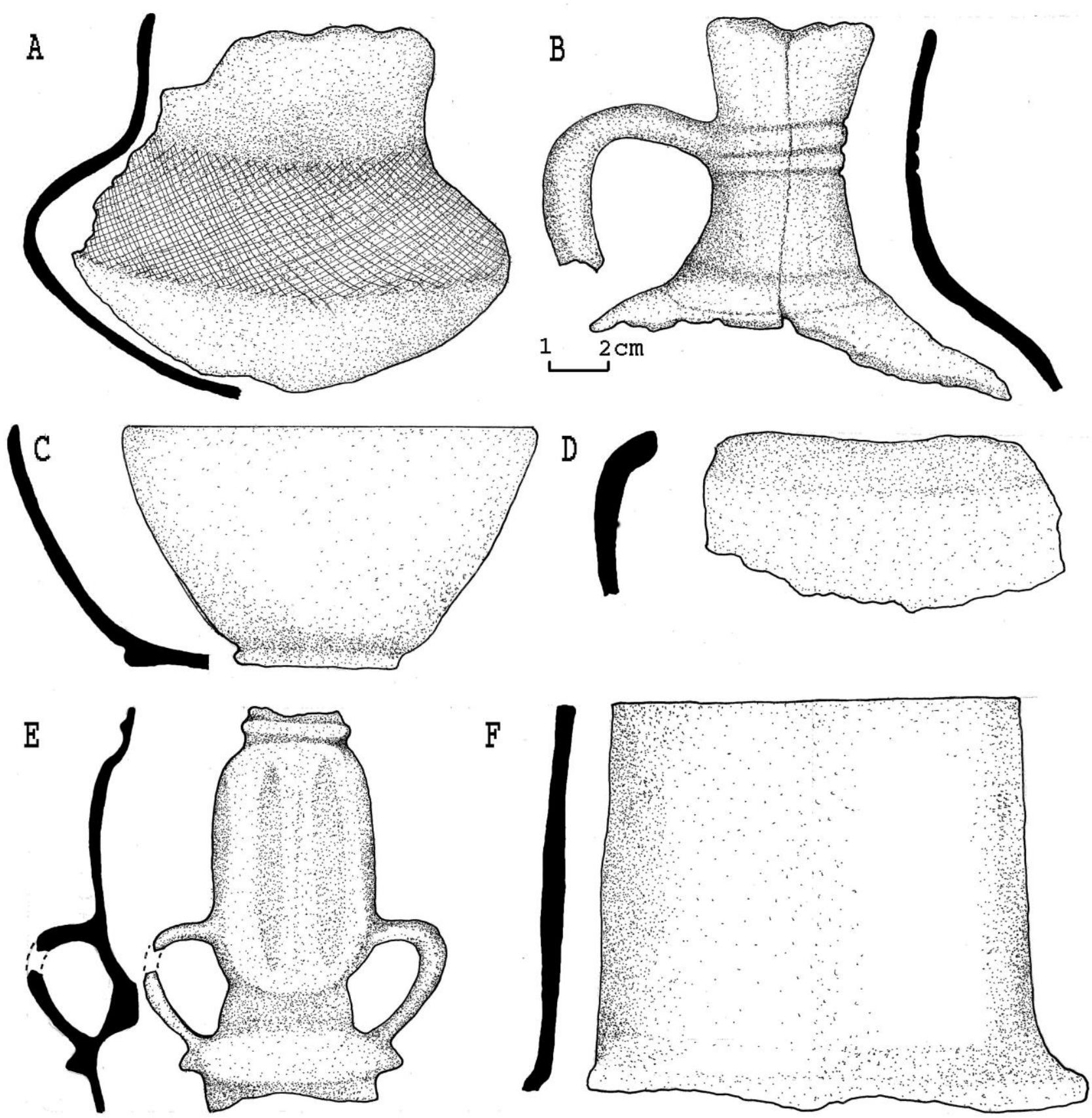

Figure 11. Artefacts from the anchorage site at Kilwa Kisiwani Port. A: No.5 Incised ware, B:

No.11 Imported jug top, C: No.6 Food Bowl, D: No. 2 (artefact spread) bowl with inturned rim, E: No.2 (artefact spread) incense burner, F: No.9 Storage vessel neck. (E. Ichumbaki and S. Kilindo) 

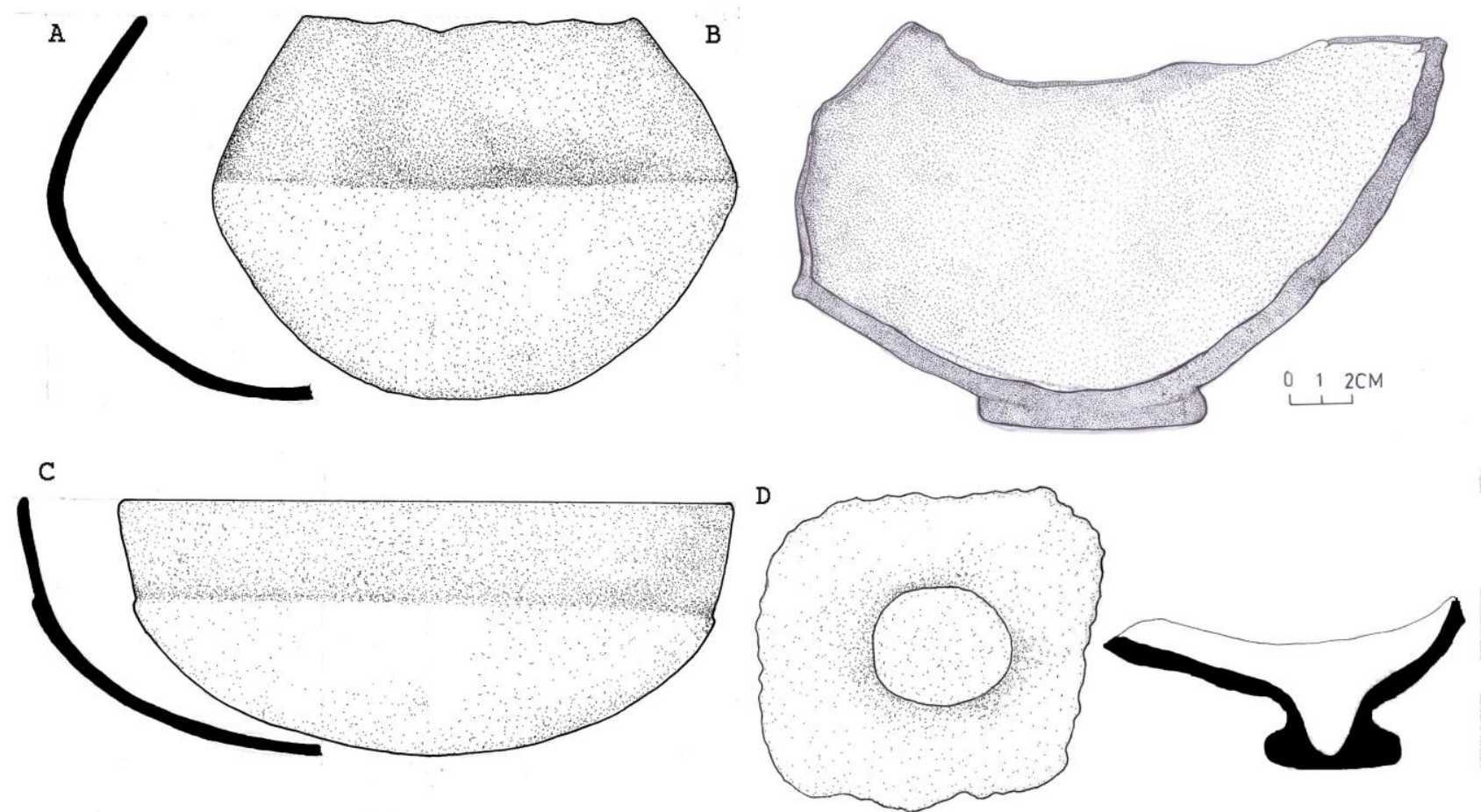

Figure 12. Artefacts from the anchorage site at Kilwa Kisiwani Port. A: No.7 Local pottery bowl, B: No.10 Islamic monochrome base, C: No.8 Local pottery bowl, D: No.6 Foot of pot (plan view of base and cross-section). (E. Ichumbaki and S. Kilindo)

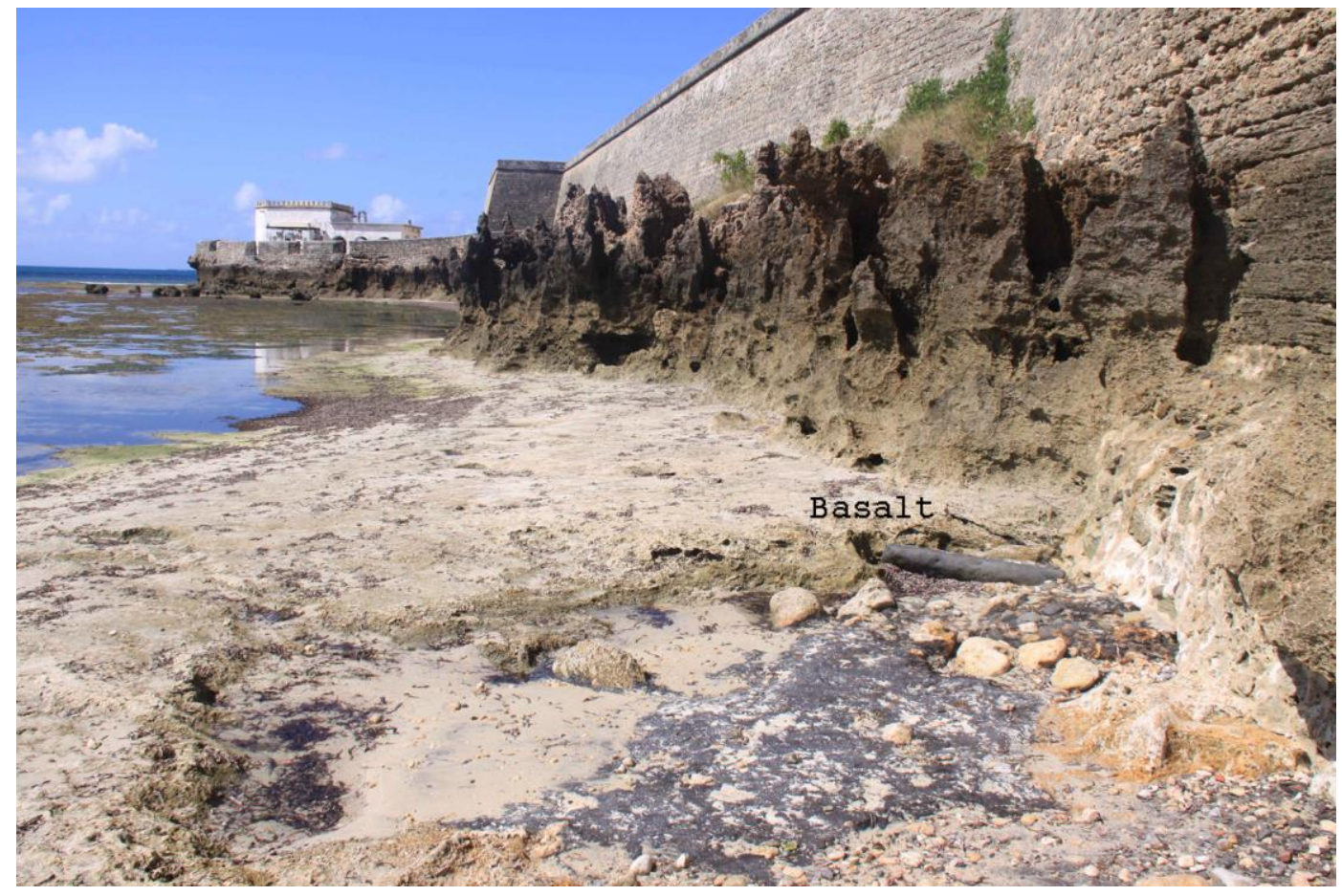

Figure 13. A large basalt block, probably ballast, on the inter-tidal zone at the base of the cliff below the 16th-century Portuguese Fort São Sebastiã, Mozambique Island. (E. Pollard) 


\begin{tabular}{|c|c|c|c|c|c|c|}
\hline $\begin{array}{l}\text { No. on } \\
\text { Fig. } 2\end{array}$ & $\begin{array}{l}\text { Site } \\
\text { name }\end{array}$ & Location & Coordinates & Date & Description & Reference \\
\hline 1 & $\begin{array}{l}\text { SMS } \\
\text { Königsber } \\
g\end{array}$ & $\begin{array}{l}\text { Rufiji } \\
\text { Delta }\end{array}$ & $\begin{array}{l}7^{\circ} 52.133^{\prime} \mathrm{S} \\
39^{\circ} 14.500^{\prime} \mathrm{E}\end{array}$ & 6 July 1915 & $\begin{array}{l}\text { German cruiser built in } 1907 . \\
\text { The ship was scuttled and the } \\
\text { guns were salvaged }\end{array}$ & $\begin{array}{l}\text { Patience } \\
\text { (2006: 157-8) }\end{array}$ \\
\hline 2 & $\begin{array}{l}\text { Newbridg } \\
e\end{array}$ & $\begin{array}{l}\text { Simba } \\
\text { Uranga } \\
\text { channel, } \\
\text { Rufiji } \\
\text { Delta }\end{array}$ & $\begin{array}{l}7^{\circ} 47.167^{\prime} \mathrm{S} \\
39^{\circ} 22.500^{\prime} \mathrm{E}\end{array}$ & $\begin{array}{l}10 \\
\text { November } \\
1914\end{array}$ & $\begin{array}{l}\text { Built in England in } 1906 \text { and } \\
\text { known as a turret ship. } \\
\text { Chartered to the Admiralty } \\
\text { with a consignment of coal. } \\
\text { Scuttled across the Rufiji } \\
\text { mouth as a blockade against } \\
\text { Königsberg. }\end{array}$ & $\begin{array}{l}\text { Patience } \\
(2006: 169- \\
70)\end{array}$ \\
\hline 3 & Somali & $\begin{array}{l}\text { Rufiji } \\
\text { Delta }\end{array}$ & $\begin{array}{l}7^{\circ} 51.334^{\prime} \mathrm{S} \\
39^{\circ} 18.900^{\prime} \mathrm{E}\end{array}$ & $\begin{array}{l}\text { November } \\
1914\end{array}$ & $\begin{array}{l}\text { Built in Germany in } 1889 \text {, it } \\
\text { supplied Königsberg with } \\
\text { coal. The cruiser HMS } \\
\text { Chatham shelled the Somali, } \\
\text { which caught fire and burnt } \\
\text { for four days becoming a } \\
\text { total loss. }\end{array}$ & $\begin{array}{l}\text { Patience } \\
\text { (2006: 184-5) }\end{array}$ \\
\hline 4 & $\begin{array}{l}\text { Wreck } \\
\text { No. } \\
79842\end{array}$ & $\begin{array}{l}\text { SE of } \\
\text { Songo } \\
\text { Mnara }\end{array}$ & $\begin{array}{l}9^{\circ} 06.840^{\prime} \mathrm{S} \\
39^{\circ} 38.700^{\prime} \mathrm{E}\end{array}$ & - & $\begin{array}{l}\text { Water Depth } 690 \mathrm{~m} \text {, } \\
\text { originally detected } 2012, \\
\text { recorded as ten containers } \\
\text { filled with concrete. }\end{array}$ & UKHO \\
\hline 5 & $\begin{array}{l}\text { Wreck } \\
\text { No. } \\
42549\end{array}$ & $\begin{array}{l}\text { Lukila, } \\
\text { Kilwa }\end{array}$ & $\begin{array}{l}8^{\circ} 54.110^{\prime} \mathrm{S} \\
39^{\circ} 35.540^{\prime} \mathrm{E}\end{array}$ & $\begin{array}{l}\text { Probably } \\
\text { 20th century }\end{array}$ & $\begin{array}{l}\text { Water depth } 2 \text { m on coral } \\
\text { substrate. Originally detected } \\
1964 . \text { Wreck of a schooner } \\
\text { on windward side of coral } \\
\text { island near Kilwa Masoko. }\end{array}$ & $\begin{array}{l}\text { UKHO; } \\
\text { Patience } \\
(2006: 231)\end{array}$ \\
\hline 6 & $\begin{array}{l}\text { Wreck } \\
\text { No. } \\
42548\end{array}$ & Lindi Bay & $\begin{array}{l}9^{\circ} 59.625^{\prime} \mathrm{S} \\
39^{\circ} 43.190^{\prime} \mathrm{E}\end{array}$ & $\begin{array}{l}\text { Probably } \\
20^{\text {th }} \text { century }\end{array}$ & $\begin{array}{l}\text { Stranded wreck identified } \\
\text { from aerial photo. Water } \\
\text { depth } 1 \mathrm{~m} \text { on coral substrate. }\end{array}$ & UKHO \\
\hline 7 & $\begin{array}{l}\text { Wreck } \\
\text { Number } \\
42547\end{array}$ & Lindi Bay & $\begin{array}{l}9^{\circ} 59.842 \text { 'S } \\
39^{\circ} 43.157^{\prime} \mathrm{E}\end{array}$ & $\begin{array}{l}\text { Probably } \\
20^{\text {th }} \text { century }\end{array}$ & $\begin{array}{l}\text { Stranded wreck identified } \\
\text { from aerial photo. Water } \\
\text { depth } 0 \mathrm{~m} \text { on coral substrate }\end{array}$ & UKHO \\
\hline 8 & $\begin{array}{l}\text { Wreck } \\
\text { Number } \\
42471\end{array}$ & Lindi Bay & $\begin{array}{l}10^{\circ} 00.784^{\prime} \mathrm{S} \\
39^{\circ} 42.850^{\prime} \mathrm{E}\end{array}$ & $\begin{array}{l}\text { Probably } \\
20^{\text {th }} \text { century }\end{array}$ & $\begin{array}{l}\text { Stranded wreck identified } \\
\text { from aerial photo. Water } \\
\text { depth } 0 \mathrm{~m} \text { on coral substrate. } \\
\text { Detected } 1964 \text {. }\end{array}$ & UKHO \\
\hline 9 & $\begin{array}{l}\text { Wreck } \\
\text { Number } \\
42471 .\end{array}$ & Lindi Bay & $\begin{array}{l}10^{\circ} 00.784^{\prime} \mathrm{S} \\
39^{\circ} 42.850^{\prime} \mathrm{E}\end{array}$ & $\begin{array}{l}\text { Probably } \\
20^{\text {th }} \text { century }\end{array}$ & $\begin{array}{l}\text { Stranded wreck identified } \\
\text { from aerial photo. Water } \\
\text { depth } 0 \mathrm{~m} \text { on coral substrate. } \\
\text { Detected } 1964 .\end{array}$ & UKHO \\
\hline 10 & Unknown & $\begin{array}{l}\text { Ras } \\
\text { Kipakone }\end{array}$ & $\begin{array}{l}8^{\circ} 57^{\prime} 4.8^{\prime \prime} \mathrm{S} \\
39^{\circ} 31^{\prime} 55.12^{\prime \prime} \\
\mathrm{E}\end{array}$ & $\begin{array}{l}\text { Late- } 18^{\text {th }} \\
\text { century }\end{array}$ & $\begin{array}{l}\text { A wreck marked as ' } L a \\
\text { Carcasse' on the inter-tidal } \\
\text { zone of Isle de Quiloa chart, } \\
1775, \text { It is } c .80 \times 16 \mathrm{~m} \text { in size. }\end{array}$ & $\begin{array}{l}\text { Bibliothèque } \\
\text { nationale de } \\
\text { France, } \\
\text { Department } \\
\text { Cartes et } \\
\text { plans, GE C- } \\
\text { 2308, } \\
\text { gallica.bnf.fr }\end{array}$ \\
\hline 11 & Unknown & $\begin{array}{l}\text { Between } \\
\text { Kilwa and } \\
\text { Mafia }\end{array}$ & - & 1777 & $\begin{array}{l}\text { Abdalla of Kilwa loaded two } \\
\text { vessels and sent them to } \\
\text { Kilwa from Mafia in January } \\
\text { 1777. Both ran onto the rocks } \\
\text { between Kilwa and Mafia, } \\
\text { and were lost with their } \\
\text { cargoes. }\end{array}$ & $\begin{array}{l}\text { Ross and } \\
\text { Holtzappel } \\
\text { (1986 in } \\
\text { Jeffery and } \\
\text { Parthesius, } \\
\text { 2012: } 162)\end{array}$ \\
\hline 12 & Unknown & $\begin{array}{l}\text { North } \\
\text { from } \\
\text { Kilwa } \\
\text { Kisiwani }\end{array}$ & - & $\begin{array}{l}\text { Portuguese } \\
\text { period }\end{array}$ & $\begin{array}{l}\text { Three Portuguese ships } \\
\text { wrecked heading north from } \\
\text { Kilwa Kisiwani. One ship } \\
\text { struck a reef after leaving the } \\
\text { harbour, the second was lost }\end{array}$ & $\begin{array}{l}\text { Theal (1898, } \\
1901 \text { in } \\
\text { Jeffery and } \\
\text { Parthesius } \\
\text { (2012: } 162)\end{array}$ \\
\hline
\end{tabular}




\begin{tabular}{|c|c|c|c|c|c|c|}
\hline & & & & & $\begin{array}{l}\text { after leaving Kilwa Kisiwani, } \\
\text { while the third struck the } \\
\text { 'bar' and was lost. }\end{array}$ & \\
\hline 13 & Unknown & $\begin{array}{l}\text { Lukila, } \\
\text { Kilwa }\end{array}$ & - & $\begin{array}{l}\text { Portuguese } \\
\text { period }\end{array}$ & $\begin{array}{l}\text { An iron anchor with a shaft } \\
\text { length of } 2.4 \mathrm{~m} \text { and } \\
\text { measuring } 1.9 \mathrm{~m} \text { from fluke to } \\
\text { fluke. It lies flat on the } \\
\text { seabed located in about } 5 \mathrm{~m} \\
\text { of water at low tide. The } \\
\text { anchor is located on a bed of } \\
\text { hard limestone where the } \\
\text { remains of light, small ships } \\
\text { could have been broken-up. }\end{array}$ & $\begin{array}{l}\text { Jeffery and } \\
\text { Parthesius } \\
\text { (2012: 162) }\end{array}$ \\
\hline 14 & Unknown & $\begin{array}{l}\text { Kisimani } \\
\text { Mafia }\end{array}$ & - & Medieval & $\begin{array}{l}\text { On the seabed was a large } \\
\text { timber which local villagers } \\
\text { reported as the keel of a } \\
\text { dhow. The area also } \\
\text { contained six large stones } \\
\text { carved in distinguishable } \\
\text { shapes, with a large central } \\
\text { hole that passes through each } \\
\text { stone. }\end{array}$ & $\begin{array}{l}\text { Jeffery and } \\
\text { Parthesius } \\
(2012: 166-8)\end{array}$ \\
\hline 15 & Unknown & $\begin{array}{l}\text { Juani } \\
\text { Island, } \\
\text { Mafia }\end{array}$ & - & $19^{\text {th }}$ century & $\begin{array}{l}\text { Ten brass cannons, three } \\
\text { anchors, fragments of shot } \\
\text { and a bronze bell were } \\
\text { located by divers in shallow } \\
\text { water close to the southern } \\
\text { shore off Juani Island, Mafia, } \\
\text { in } 1977 \text {. The bell was } \\
\text { recovered and bore the } \\
\text { following inscription: 'H ... } \\
\& B \text { H Co. } 180 \text { ' (the last } \\
\text { figure might be 9). }\end{array}$ & $\begin{array}{l}\text { ARDA (1980: } \\
\text { 9) }\end{array}$ \\
\hline 16 & $\begin{array}{l}\text { Wreck } \\
\text { number } \\
42523 .\end{array}$ & $\begin{array}{l}\text { NE of } \\
\text { Kwale } \\
\text { Island }\end{array}$ & $\begin{array}{l}7^{\circ} 21.732^{\prime} \mathrm{S} \\
39^{\circ} 32.538^{\prime} \mathrm{E}\end{array}$ & - & $\begin{array}{l}\text { In } 30 \mathrm{~m} \text { water depth on mud } \\
\text { substrate. Foul reported } \\
\text { originally in } 1916\end{array}$ & UKHO \\
\hline 17 & Unknown & Off Kilwa & - & 1519 & $\begin{array}{l}\text { Portuguese ship grounded on } \\
\text { a sandbank off Kilwa. The } 10 \\
\text { crew were, all but one youth, } \\
\text { killed by people from Kilwa, } \\
\text { Mafia and Zanzibar. }\end{array}$ & $\begin{array}{l}\text { Strandes } \\
\text { (1977: 99) }\end{array}$ \\
\hline 18 & Unknown & Mafia & - & - & A wooden shipwreck & $\begin{array}{l}\text { Patience } \\
(2006: 231)\end{array}$ \\
\hline
\end{tabular}

Table 1. Recorded and reported wreck-sites in the area surrounding Kilwa 
Table 2. Recorded artefacts from Kilwa Kisiwani Port anchorage site

\begin{tabular}{|c|c|c|c|}
\hline $\begin{array}{l}\text { No. on } \\
\text { Fig. } 8\end{array}$ & Description & Interpretation & Date \\
\hline 2 & $\begin{array}{l}\text { (Artefact spread) This fine grained red } \\
\text { matrix vessel has two handles on the two } \\
\text { sides but one is partly broken. Between the } \\
\text { handles are circular indentions whose size } \\
\text { decreases towards the base. Similar circular } \\
\text { indentions are placed on the neck area. }\end{array}$ & $\begin{array}{l}\text { A similar but closed on one side } \\
\text { vessel reported by Wynne-Jones } \\
\text { (pers. comm.) from Vumba Kuu on } \\
\text { the Kenyan coast is interpreted as an } \\
\text { incense burner. }\end{array}$ & $\begin{array}{l}14 \text { th to } 15 \text { th } \\
\text { century }\end{array}$ \\
\hline 2 & (Artefact spread) Bowl with inturned rim & $\begin{array}{l}\text { Local pottery, Red burnished ware } \\
\text { type } 9 \text { or } 11 \text { (Chittick, 1974: } 323-4)\end{array}$ & $\begin{array}{l}\text { Late-12th to } \\
13 \text { th century }\end{array}$ \\
\hline 2 & $\begin{array}{l}\text { (Artefact spread) A nearly complete Islamic } \\
\text { monochrome bowl with red matrix and dark } \\
\text { green glaze. }\end{array}$ & $\begin{array}{l}\text { Standard monochrome (Chittick, } \\
\text { 1974: 304). }\end{array}$ & $\begin{array}{l}\text { Mid- } 15 \text { th to } \\
16 \text { th century }\end{array}$ \\
\hline 2 & $\begin{array}{l}\text { (Artefact spread) Enclosed bowl } \\
\text { earthenware fragment. Fine-grained matrix. }\end{array}$ & $\begin{array}{l}\text { Type } 20 \text { of ceramic phase C: Late } \\
\text { Tana Tradition has single or double } \\
\text { row of horizontal fingernail } \\
\text { impressions along rim or carination, } \\
\text { Horton (1996: } 262)\end{array}$ & $\begin{array}{l}13 \text { th to } 14 \text { th } \\
\text { century }\end{array}$ \\
\hline 5 & $\begin{array}{l}\text { (dGPS potter1) Local incised ware vessel } \\
\text { decorated between neck and shoulder. }\end{array}$ & $\begin{array}{l}\text { Type 25a globular cooking-pots with } \\
\text { incised decoration mostly hatched on } \\
\text { the shoulder (Chittick, 1974: 328). }\end{array}$ & 16th century \\
\hline 6 & $\begin{array}{l}\text { An unglazed pottery base found near } \\
\text { GPS365, 48mm diameter, with a high stand } \\
\text { (foot). }\end{array}$ & $\begin{array}{l}\text { Possibly an incense burner. Chittick } \\
\text { interprets similar artefact from } \\
\text { Manda (1984: 100) as a leg of stand } \\
\text { or table. }\end{array}$ & $\begin{array}{l}\text { Mid-9th to } \\
\text { early-11th } \\
\text { century }\end{array}$ \\
\hline 6 & (GPS365) Local pottery bowl & $\begin{array}{l}\text { Burnished food bowls. Types } 16 \text { and } \\
17 \text { (Chittick, 1974: 325) }\end{array}$ & $\begin{array}{l}15 \text { th to } 17 \text { th } \\
\text { century }\end{array}$ \\
\hline 7 & (GPS370) Complete local pottery bowl & $\begin{array}{l}\text { Early burnished ware. Type } 11 \\
\text { (Chittick, 1974: 324) }\end{array}$ & $\begin{array}{l}\text { Late-12th to } \\
13 \text { th century }\end{array}$ \\
\hline 8 & (GPS367) Half of a local pottery bowl & $\begin{array}{l}\text { Possibly Horton's (1994: 258) Type } \\
12\end{array}$ & $\begin{array}{l}10 \text { th to mid- } \\
11 \text { th century }\end{array}$ \\
\hline 9 & (GPS368) Storage vessel neck & $\begin{array}{l}\text { Type } 33 \text { large globular water-pots } \\
\text { have near vertical necks, Chittick } \\
(1974: 329)\end{array}$ & $\begin{array}{l}\text { Late-12th to } \\
15 \text { th century }\end{array}$ \\
\hline 10 & $\begin{array}{l}\text { (GPS371) Base of pot, dark green glaze } \\
\text { Islamic monochrome with red matrix }\end{array}$ & $\begin{array}{l}\text { Standard monochrome (Chittick, } \\
\text { 1974: 304) }\end{array}$ & $\begin{array}{l}\text { Mid- } 15 \text { th to } \\
16 \text { th century }\end{array}$ \\
\hline 11 & $\begin{array}{l}\text { (GPS366) Jug top with incised cross-hatched } \\
\text { decoration on the shoulder with a thickness } \\
\text { of } 4-5 \mathrm{~mm}\end{array}$ & $\begin{array}{l}\text { Possibly similar to handled vessels in } \\
\text { buff fabric from Manda (Chittick, } \\
\text { 1984: 94). Horton (1996: 297-8) has } \\
\text { fine creamwares (3-5 mm thick) from } \\
\text { Siraf in early Islamic occupation at } \\
\text { layers at Shanga. }\end{array}$ & $\begin{array}{l}\text { Mid-9th to } \\
\text { early-11th } \\
\text { century }\end{array}$ \\
\hline
\end{tabular}

